\title{
Review of the genus Loimia Malmgren, 1866 (Annelida, Terebellidae) from China seas with recognition of two new species based on integrative taxonomy
}

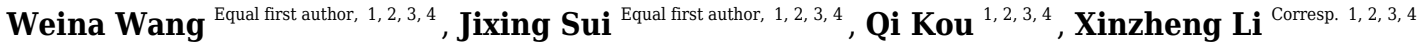 \\ 1 Department of Marine Organism Taxonomy and Phylogeny, Institute of Oceanology, Chinese Academy of Sciences, Qingdao, China \\ 2 University of Chinese Academy of Sciences, Beijing, China \\ 3 Center for Ocean Mega-Science, Chinese Academy of Sciences, Qingdao, China \\ 4 Laboratory for Marine Biology and Biotechnology, Qingdao National Laboratory for Marine Science and Technology, Qingdao, China \\ Corresponding Author: Xinzheng Li \\ Email address: lixzh@qdio.ac.cn
}

Specimens of the genus Loimia (Annelida, Terebellidae) deposited in the Marine Biological Museum of the Chinese Academy of Sciences (MBMCAS) together with materials newly collected from China seas were examined. Based on morphological comparisons and molecular analysis, some specimens collected from the coasts of Shandong province and Guangxi province were confirmed as two new Loimia species respectively (Loimia borealis sp. n. and Loimia macrobranchia sp. n.). Morphologically, L. borealis sp. n. is distinguished from previously known species of this genus by having seven equal sized ventral shields, with length five times the width; this species was retrieved as sister to the clades of Loimia arborea Moore, 1903 and Loimia bandera Hutchings, 1990 in the phylogenetic tree, which was reconstructed based on mitochondrial COI gene. Loimia macrobranchia sp. n. differs from congeners by the large size of its first pair of branchiae with a thick main stem and about 18 dendritic branches arranged in two levels. A key to identifying Loimia species found in Chinese seas is given. 


\section{Review of the genus Loimia Malmgren, 1866 (Annelida,}

\section{Terebellidae) from China seas with recognition of two new}

\section{3 species based on integrative taxonomy}

5 Weina Wang1234, Jixing Sui1234, Qi Kou1234, Xinzheng Li1234

61 Department of Marine Organism Taxonomy and Phylogeny, Institute of Oceanology, Chinese Academy

7 of Sciences, 7 Nanhai Road, Qingdao 266071, China

82 University of Chinese Academy of Sciences, Beijing 100049, China

93 Center for Ocean Mega-Science, Chinese Academy of Sciences, Qingdao, China

104 Laboratory for Marine Biology and Biotechnology, Qingdao National Laboratory for Marine Science

11 and Technology, Qingdao 266000, China

12

13 Corresponding Author:

14 Xinzheng Li

157 Nanhai Road, Qingdao, Shandong, 266071, China

16 Email address: lixzh@qdio.ac.cn 


\section{Review of the genus Loimia Malmgren, 1866}

18

19

20

21

22

23

24

25

26

27

28

29

30

31

32

33

34

35

36

37

38

39

40

41

42

43

44

45

46

47

48

49

(Annelida, Terebellidae) from China seas with

recognition of two new species based on integrative taxonomy

Weina Wang ${ }^{1234}$, Jixing Sui ${ }^{1234}$, Qi Kou ${ }^{1234}$, Xinzheng Li $^{1234}$

${ }^{1}$ Department of Marine Organism Taxonomy and Phylogeny, Institute of Oceanology, Chinese Academy of Sciences, 7 Nanhai Road, Qingdao 266071, China

${ }^{2}$ University of Chinese Academy of Sciences, Beijing 100049, China

${ }^{3}$ Center for Ocean Mega-Science, Chinese Academy of Sciences, Qingdao, China

${ }^{4}$ Laboratory for Marine Biology and Biotechnology, Qingdao National Laboratory for Marine Science and Technology, Qingdao 266000, China

Corresponding Author:

Xinzheng Li ${ }^{1234}$

7 Nanhai Road, Qingdao, Shandong, 266071, China

Email address: lixzh@qdio.ac.cn

\section{Abstract}

Specimens of the genus Loimia (Annelida, Terebellidae) deposited in the Marine Biological Museum of the Chinese Academy of Sciences (MBMCAS), together with materials newly collected from Chinese seas, were examined. Based on morphological comparisons and molecular analyses, some specimens collected from Shandong and Guangxi Provinces were confirmed as new Loimia species, namely Loimia borealis sp. n. and Loimia macrobranchia sp. n., respectively. Morphologically, L. borealis sp. $\mathrm{n}$. is distinguished from other species of this genus in that it has seven equal-sized ventral shields, each with a length five times the width. This species was retrieved as a sister to the clades of Loimia arborea Moore, 1903 and Loimia bandera Hutchings, 1990 in the phylogenetic tree, which was reconstructed based on the mitochondrial cytochrome oxidase subunit 1(COI) gene. Loimia macrobranchia sp. n. differs from congeners by its large first pair of branchiae, which consist of a thick main stem and approximately 18 dendritic branches arranged in two levels. A key to identifying Loimia species found in Chinese seas is given. 
50 Introduction

51 Terebellids are common sedentary polychaetes in marine bottoms, found worldwide from

52 shallow water to deep-sea environments (Rouse \& Pleijel, 2001). They are selective deposit

53 feeders using long, grooved and ciliated buccal tentacles to collect sediment and organic matters

54 (Fauchald \& Jumars, 1979; Jumars et al., 2015).

55 Terebellidae Johnston, 1846 is the largest family of Terebelliformia. A recent review of

56 Terebellidae Johnston, 1846 has been undertaken by Hutchings et al. (2017). According to

57 Hutchings et al. (2017), Terebellidae has 44 genera currently, several of which are monotypic.

58 The genus Loimia Malmgren, 1865 comprises 29 valid species occurring worldwide, and most of 59 them are found in tropical areas (Lavesque et al., 2017). Live specimens of Loimia, living in

60 tubes, are usually large and brightly colorful, with long, grooved tentacles and blood-red regions

61 at the termination of mid-ventral shields (Nogueira, Hutchings \& Carrerette, 2015).

62 According to Liu (2008), five species have been documented from Chinese seas: Loimia 63 arborea Moore, 1903; Loimia ingens (Grube, 1878); Loimia medusa (Savigny,1818); Loimia 64 bandera Hutchings, 1990 and Loimia montagui (Grube, 1878). Loimia arborea was described 65 from Suruga Bay in Japan (Moore, 1903). Loimia bandera was described from Hong Kong 66 (Hutchings, 1990). Loimia montagui and Loimia ingens was described by Grube (1878) from the 67 Philippines. Hutchings \& Glasby (1988) examined the materials of L. ingens from Australian 68 waters and suggested that $L$. ingens should be treated as a species complex. Afterwards, they 69 checked materials from Hong Kong and suggested it seemed preferable to refer the Hong Kong 70 material to the Loimia ingens species complex. They also recommended that more material from 71 the Indo-Pacific was needed to be examined before splitting up the complex (Hutchings \&Glasby 72 ,1990). Loimia medusa, the type species of the genus Loimia, was described from Lamark by 73 Savigny (1818) but the original descriptions lacked detailed illustrations of diagnostic characters 74 and type material has never been deposited in any museum (Carrerette \& Nogueira, 2015).

75 Hutchings \& Glasby (1988) referred specimens previously identified as L. medusa from 76 Australia to a new species, and suggested that L. medusa does not occur in Australian waters. 77 Subsequently they redescribed L. medusa based on materials collected close to the type locality 78 and assigned a neotype. They also suggested that the species was restricted to the Arabian Sea 79 region and in many cases reports from other distant localities might be misidentification 80 (Hutchings \& Glasby, 1995). 
81

82

83

84

85

86

87

88

89

90

91

92

93

94

95

96

97

98

99

100

101

102

103

104

105

106

107

108

109

110

111

Recently, some specimens of Terebellidae were collected during two surveys in Shandong and Guangxi provinces in China. After observation, these specimens were confirmed as Loimia species with lobes on segments 1 and 3, three pairs of branchiae on segments 2-4, rectangular mid-ventral shields from segments 2 to the posterior region where notopodia terminate, 17 pairs of notopodia beginning from segment 4 , neuropodia beginning from segment 5 , bearing pectinate uncini arranged in single rows on segment 5-10 and in double rows on segments 11-20. Since these Loimia specimens were never described before, we herein formally describe them as new species to science. In addition to morphological analyses, we performed a barcoding analysis using sequences of the mitochondrial COI gene to help the identification of specimens.

\section{Materials \& Methods}

\section{Sample collection and morphological examination}

Specimens of Loimia were collected from coastal areas of Chinese seas (Table 1). The collected specimens were anaesthetized with 7\% magnesium chloride $(\mathrm{MgCl} 2)$ and photographed using a Canon EOS 600D camera. Thereafter they were preserved in 75\% ethanol. All specimens were deposited in the MBMCAS. Specimens were observed, measured, and photographed with a Nikon SMZ25 stereomicroscope. The detailed morphology of the lobes, notochaetae, and uncini was observed and documented with a Nikon Ni-U stereomicroscope and a Hitachi S-3400N scanning electron microscope (SEM).

\section{Molecular data and analysis}

DNA was extracted from 17 individuals collected from various coastal areas of Chinese seas that represented five morphologically distinct species of the genus Loimia (Table 1). Total DNA was extracted with the DNeasy ${ }^{\circledR}$ Blood and Tissue Kit (Qiagen, Hilden, Germany) and stored at $-20^{\circ} \mathrm{C}$. Partial fragments (approximately $700 \mathrm{bp}$ ) of the COI gene were amplified by the polymerase chain reaction (PCR) using primers LCO1490/HCO2198, LCO1490/CO1-E, polyLCO/polyHCO, and polyLCO/polyshortCOIR. The primer information is given in Table 2 . Amplifications were carried out in a reaction mixture containing $2 \mu 1$ of template DNA, $12.5 \mu 1$ of Premix Taq ${ }^{\mathrm{TM}}$ (Takara, Otsu, Shiga, Japan), $0.5 \mu 1$ of each primer (stock concentration, 10 $\mathrm{mM}$ ), and sterile distilled $\mathrm{H}_{2} \mathrm{O}$ to a total volume of $25 \mu \mathrm{l}$ with cycling conditions as follows: initial denaturation at $94{ }^{\circ} \mathrm{C}$ for $10 \mathrm{~min}$, followed by 35 cycles of denaturation at $94{ }^{\circ} \mathrm{C}$ for $30 \mathrm{~s}$, annealing at $45^{\circ} \mathrm{C}$ for $40 \mathrm{~s}$, and extension at $72^{\circ} \mathrm{C}$ for $30 \mathrm{~s}$. A final extension at $72{ }^{\circ} \mathrm{C}$ for $10 \mathrm{~min}$ was included. PCR-products generating distinct bands after electrophoresis on 1\% agarose gels 
112 were sent to the Qingke Laboratory (Qingdao, China) for sequencing using the same set of 113 primers that was used for PCR. Fragments with overlapping sequences (forward and reverse) 114 were merged into consensus sequences using CONTIG EXPRESS (a component of Vector NTI 115 Suite 6.0, Life Technologies, Carlsbad, CA, USA). The assembled sequences were checked by 116 searching BLAST in GenBank to ensure that the DNA was not contaminated.

117 In addition to the sequences obtained by PCR, we downloaded all COI gene sequences of 118 Loimia species from GenBank. COI gene sequences of two species from the family Terebellidae, 119 namely Pista cristata Müller, 1776 and Terebella lapidaria Linnaeus, 1767 were also 120 downloaded as the outgroups for phylogenetic analysis (Table 1).

Molecular data, including 31 sequences of the COI gene, were aligned using MUSCLE 3.8

122 (Edgar, 2004). Highly divergent and poorly aligned sites were omitted from the alignment 123 according to Gblocks 0.91 b (Castresana, 2000). The best-fitting nucleotide base substitution model $(\mathrm{GTR}+\mathrm{F}+\mathrm{I}+\mathrm{G} 4)$ for the alignment data was determined in IQTREE with ModelFinder (Kalyaanamoorthy et al., 2017), and a maximum likelihood tree was constructed using IQTREE (Nguyen et al., 2015) with 1,000 bootstrap reiterations (Hoang et al., 2018). A Bayesian inference tree was constructed using MrBayes 3.2 (Huelsenbeck \& Ronquist, 2001). Markov chains were run for 10,000,000 generations and sampled every 100 generations. The first $25 \%$ of trees were discarded as burn-in, and the remaining trees were used to construct the $50 \%$ majority-rule consensus tree and to estimate posterior probabilities. Genetic distances were calculated using the Kimura's two-parameter model in MEGA 7.0 (Kumar, Stecher \& Tamura, 2016). Finally, all the sequences obtained in this study were submitted to GenBank (Table 1).

133

134

135

136

137

138

139

140

141

142

\section{Zoobank registration}

The electronic version of this article in portable document format will represent a published work according to the International Commission on Zoological Nomenclature (ICZN), and hence the new names contained in the electronic version are effectively published under that Code from the electronic edition alone. This published work and the nomenclatural acts it contains have been registered in ZooBank, the online registration system for the ICZN. The ZooBank Life Science Identifiers (LSIDs) can be resolved and the associated information viewed through any standard web browser by appending the LSID to the prefix http://zoobank.org/. The LSID for this publication is: urn:1sid:zoobank.org:pub:06667411-789A-49C9-AC12-8DA2858341E9. The online 
143 version of this work is archived and available from the following digital repositories: Peer J,

144 PubMed Central, and CLOCKSS.

145 Results

146 Taxonomy

147 Family Terebellidae Johnston, 1846

148 Genus Loimia Malmgren, 1866

149 Type species: Terebella medusa Savigny in Lamark, 1818

150 Diagnosis. Eyespots, if present, at basal part of prostomium; lobes on segments 1 and 3 or 1 and $1512 / 3$ (in combination of segment 2 and 3), sometimes also on segment 4 . Three pairs of branching 152 branchiae, on segments 2-4. Rectangular or trapezoidal mid-ventral shields from segments 2-3 153 to posterior region where notopodia terminate; the last segments of the glandular region usually 154 subdivided into transverse bands. Conical to rectangular notopodia beginning on segment 4, 155 extending for 17 segments, until segment 20; notochaetae all narrowly-winged. Neuropodia 156 beginning from segment 5, bearing pectinate uncini, arranged in single rows on segment 5-10 157 and in double rows on segments 11-20. Genital papillae on segments 6-8. Pygidium smooth to 158 papillate (Carrerette \& Nogueira, 2015; Nogueira, Hutchings \& Carrerette, 2015).

159 Remarks. Loimia species are normally found in tropical areas, with only a few species 160 inhabiting subtropical areas, and no species inhabiting Arctic areas (Lavesque et al., 2017). The 161 genus Loimia can be distinguished by the presence of pectinate uncini, a feature unique to 162 Terebellidae (Nogueira, Hutchings \& Carrerette, 2015). Other characteristics useful in the 163 identification of species within this genus are: (1) the shape and position of the lobes on 164 segments 1 and 3; (2) the number, arrangement, and shape of the mid-ventral glandular shields; 165 and (3) the number and morphology of uncinial teeth from both anterior and posterior regions 166 (Hutchings \& Glasby, 1988, 1995; Hutchings, 1997; Londoño-Mesa \& Carrera-Parra, 2005; 167 Londoño-Mesa, 2009; Carrerette \& Nogueria, 2015).

168 Loimia borealis sp. n.

169 Figs $1-4$

170 Materials examined. Holotype: MBM286585, mud-flat, Yangkou Village, Shandong province

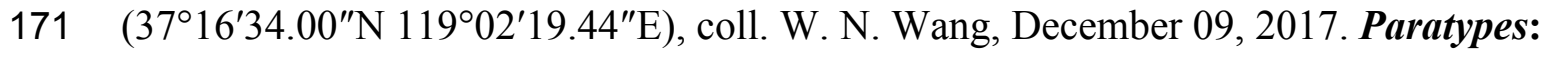

172 MBM286586-MBM286593, eight specimens, same collection data as holotype. 
173 Additional material examined. MBM199208, Cangkou, Qingdao (36 $11^{\prime} 28.44^{\prime \prime} \mathrm{N}$

$\left.174120^{\circ} 22^{\prime} 55.40^{\prime \prime} \mathrm{E}\right)$, intertidal, August 21, 1958. MBM199302, Cangkou, Qingdao (36¹1'28.44"N

$\left.175120^{\circ} 22^{\prime} 55.40^{\prime \prime} \mathrm{E}\right)$, intertidal, May 22, 1959.

176 Description of holotype. Complete specimen with 104 segments, $82.8 \mathrm{~mm}$ long; thorax 13.2

$177 \mathrm{~mm}$ long. Body salmon or reddish flesh-color in live specimens, with darker, yellowish mid-

178 ventral shields terminating with blood red region (Fig. 1A-C). Preserved body whitish, without

179 distinct patterns of pigmentation (Fig. 2A-C). Anterior segments compact, with posterior thoracic

180 segments longer than anterior thoracic segments (Fig. 1B); body widest over mid posterior

181 thorax, tapering gradually over abdominal segments (Fig. 1B). Anterior segments inflated

182 dorsally (Fig. 1B). Abdomen with irregular swellings (Fig. 1A). Prostomium at base of dorsal

183 surface of upper lip; basal part without eyespots; distal part shelf-like from which long and

184 grooved buccal tentacles originate (Fig. 2B-C). Peristomium restricted to lips; upper lip with

185 long free edge, projecting forward, spoon-like, shorter than wide (Figs 2B-C, 3B); thicker at the

186 base. Lower lip short, button like, partly hidden by the first pair of lateral lobes. Segment 1

187 dorsally narrow, with pair of well-developed lobes originating ventro-laterally; lobes with

188 oblique dorsal margins inserted laterally to first pair of branchiae; distally rounded, roughly

189 circular, reaching around mid-length of upper lip, mid-ventrally connected by membrane (Figs

190 2B-C, 3A-B). Segment 2 reduced, conspicuous laterally and dorsally, covered by lobes of

191 segment 3 laterally and partially fused to it mid-ventrally. Segment 3 with a pair of circular

192 lobes, twice width of notopodia, originating dorso-laterally, ventral edges fused to upper corners

193 of the first mid-ventral shield, dorsal margins inserted at level of dorsal edges of notopodia of

194 segment 4, tips extending dorsally, reaching bases of branchiae (Fig. 2B-C). Lobes of segment 4

195 absent (Fig. 3A-C). Three pairs of branched branchiae present on segments 2 to 4, all equal in

196 size, inserted progressively more laterally (Fig. 2A). Branchiae with short, thick stalks and

197 slender dendritic filaments branching dichotomously from secondary stems, originating in a

198 spiral from short basal stems (Fig. 1D). Genital papillae small, at base of notopodia of the

199 segments 6-8 (Fig. 2A-B). Seven ventral shields compact, beginning from segment 2 to segment

200 10; those of segments 2-4 almost fused into single crenulated structure, wider than those of

201 following segments, then all about the same size (Fig. 2B-C); anterior shields rectangular with

202 length five times the width, trapezoidal on segment 10; shields transversally divided on segments

203 10, from segment 11, shields replaced by mid-ventral groove extending posteriorly (Figs 2B-C, 
204 3A-B); blood red region on segments 10-13 (Fig. 1B-C). Notopodia extending from segment 4 to 20520 for 17 segments, bearing two types of notochaetae within a fascicle (Figs 3D, L, 4F, I): long 206 chaetae narrowly bilimbate (Figs 3E-F, K, 4E, H, K) and short smooth capillaries (Fig. 4J). 207 Neuropodia starting from segment 5, as glandular ridges slightly raised from surface of thorax 208 until segment on which notopodia terminate, thereafter as elongate pinnules (Figs 2B-C, F, 3A). 209 Uncini pectinate, with 5-6 teeth, higher than long, with oblique and concave base presenting 210 slight protuberance; short triangular heel directed backwards for the attachment of the long, 211 ligamental filament, with prow downwardly directed, aligned with line of teeth, connected to 212 long filament (Fig. 4A-D, G); under SEM, series of teeth with lateral fringe of minute teeth (Fig. 213 3G-J). Uncini arranged in single row until segment 10, in double rows from segment 11-20, in 214 back to back position; in single rows from segment 21 to the pygidium; abdominal uncini similar 215 in shape but smaller in size than thoracic ones. Anus surrounded by about 7 rounded papillae. 216 Tube with an inner lining of mucus covered by small stones and shell fragments.

217 Variation. The number of segments in complete specimens varies from 95 to 104. The number 218 of ventral shields varies from 7 to 9. Genital papillae absent in some specimens. In addition, 219 other morphological characteristics used for comparison are provided in Table 3.

220 Remarks. Loimia borealis sp. n. is characterized by its compact rectangular mid-ventral shields, 221 each with a length five times the width, which to our knowledge are not found in any other 222 species in the genus Loimia. Loimia arborea and L. bandera also have slender ventral shields, 223 but they differ from L. borealis sp. $\mathrm{n}$. in the shape of their broad prominent prostomia, which 224 almost surround the mouth (Fig. 5A, C, E), and their round glandular tubercles, which run in 225 longitudinal ridges on anterior segments near notopodia (Fig. 5B, D, F) (Hutchings 1990; 226 Carrerette \& Nogueira, 2015; Moore, 1903). Similar to L. borealis sp. n., Loimia ingens has 227 large round lobes on segment 3 that originate dorso-laterally and align to the base of notopodia 228 of segment 4 (Fig. 5H, J). However, L. borealis sp. n. has three pairs of equal-sized branchiae, 229 which distinguish it from L. ingens (the first pair is the longest, and the third pair is the shortest) 230 (Fig. 5I). These species are compared in Table 4.

231 Etymology. "Borealis" means northern. The species is named after its location on the northern 232 coast of China.

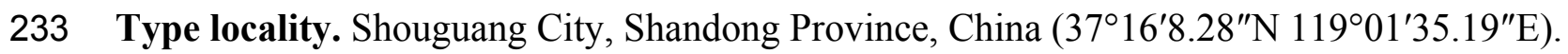

234 Distribution. Northern coast of China. 
236 Loimia macrobranchia sp. n.

237 Figs 6-8

238 Material examined. Holotype: MBM286579, Fangchenggang City, Guangxi province, China $239\left(21^{\circ} 30^{\prime} 17.65^{\prime \prime} \mathrm{N} 108^{\circ} 13^{\prime} 37.07^{\prime \prime} \mathrm{)}\right)$, intertidal, coll. J. X. Sui, October 17, 2016. Paratype:

240 MBM286580, same collection data as holotype, specimen incomplete. MBM286581, same 241 collection data as holotype, specimen complete.

242 Additional material examined. MBM199304, Shatian Port, Hepu Country, Guangxi Province, 243 China $\left(21^{\circ} 31^{\prime} 15.55^{\prime \prime} \mathrm{N} 109^{\circ} 39^{\prime} 1.41^{\prime \prime} \mathrm{E}\right)$, intertidal, April 21, 1963.

244 Description of holotype. Specimen complete, with 125 segments, $358.9 \mathrm{~mm}$ long; thorax 15.7

$245 \mathrm{~mm}$ long. Body yellowish brown in live material, with greenish branchiae and yellowish 246 inclusions. Darker, reddish and yellowish mid-ventral shields terminating with blood red 247 glandular region subdivided as transverse bands (Fig. 6A). Preserved body whitish, without 248 distinct patterns of pigmentation (Fig. 6B-E). Posterior thoracic segments longer than anterior 249 segments; body swollen anteriorly, widest over mid posterior thorax, tapering gradually over 250 abdominal segments (Fig. 6A). Notopodia beginning from segment 4 followed by 17 251 chaetigerous segments. Prostomium attached to dorsal surface of upper lip; basal part without 252 eyespots; distal part almost straight, from which buccal tentacles originate. Prostomium broad, 253 almost surrounding the mouth (Fig. 6D); upper lip with long free edge, projecting forward, 254 shorter than wide, thrown into several vertical folds with the margins corrugated (Fig. 6C-D). 255 Peristomium ventrally and laterally with a conspicuous free anterior border, ending above in a 256 pair of narrow lobes originating dorsal-laterally and reaching around 1/3 of the upper lip length, 257 mid-ventrally connected by membrane (Fig. 6C-D). Lower lip small, button like to rectangular, 258 partly hidden by the membrane the first pair of lateral lobes (Fig. 6D). Segment 2 reduced, 259 dorsally conspicuous, fused with segment 3 , laterally forming a pair of small and triangular lobes

260 (Fig. 6C). Lobes with bases wider than tips, dorsal margins aligned and fused to the notopodia of 261 segment 4 (Fig. 6C-D). Segment 4 without lateral lobes. Three pairs of branchiae on segments 2 262 to 4 with yellowish inclusion (Fig. 6B-C). First pair of branchiae large, about 3 times as large as 263 subsequent ones, with stout main stem and about 18 dendritic branches arranged in two levels on 264 the main stem (Fig. 6E). The other two pairs of branchiae being subequal. Genital papillae small, 265 at base of notopodia of the segments 6-8 (Fig. 6B). Ten ventral shields, starting from segment 2 
266 to segment 12 (Fig. 6A); the first shield on segments 2-4 completely fused into single crenulated 267 structure, being twice as long as following segments (Fig. 6D); anterior shields rectangular, all 268 about the same size (Fig. 6D); behind segment 11, the glandular region subdivided as transverse 269 bands, blood-red in live material (Fig. 6A). Bands on segment 12 and 13 trapezoid, width being 270 twice as long as anterior shields; on segment 14 and 15 the largest, almost oval in outline; on 271 segment 16 smaller than that on 15, oval in outline; subsequently bands becoming shorter and 272 narrower, disappearing by segment 19 (Fig. 6A). Notopodia from segment 4, extending for 17 273 segments (Fig. 6A, C-D); first 8 pairs of podia long, cylindrical, following ones slender, shorter 274 than anterior ones, almost inconspicuous. Notochaeta of two types (Fig. 7A, D), widely-winged, 275 long thick chaetae in both rows throughout (Figs 7B, E-F, 8A, D) and short smooth capillaries 276 (Figs 7C, 8B). Neuropodia starting from segment 5, as glandular ridges slightly raised from 277 surface of thorax until segment on which notopodia terminate, thereafter as elongate pinnules. 278 Uncini pectinate, with 5-6 teeth, higher than long, with oblique and concave base, short 279 triangular heel directed backwards for the attachment of the ligamental filament, with prow 280 downwardly directed, aligned with line of teeth, connected to long filament (Figs 7G-J, 8C, E281 G). Uncini arranged in single row until segment 10, in double rows from segment 11-20, in back 282 to back position; in single rows from segment 21 until the pygidium; abdominal uncini similar in 283 shape but smaller in size than thoracic ones. Anus rounded, without any anal papillae (Fig. 6A). 284 Tube with an inner lining of mucus covered by sand.

285 Variations. Three specimens were collected from Guangxi Province. The number of segments in 286 these specimens varies from 125 to 130, with the highest number of segments in the holotype.

287 One paratype was incomplete (length, $189 \mathrm{~mm}$; thorax, $13.1 \mathrm{~mm}$ ). It has ventral grooves shaped 288 as a trapezoid on segment 13, as a square on segment 14, and as a long rectangle on segment 15. 289 The first pair of branchiae are approximately five times larger than the subsequent ones. The 290 other paratype is complete (length, $125 \mathrm{~mm}$; thorax, $8 \mathrm{~mm}$ ), with relatively short broken 291 dendritic branchiae. The stems of the first pair of branchiae are slightly thicker than the 292 subsequent ones.

293 Remarks. Loimia macrobranchia sp. n. is characterized by the shape and size of its first pair of 294 large branchiae, which are approximately three to five times larger than subsequent ones, with a 295 thick main stem and approximately 18 dendritic branches arranged in two levels. It is easy to 296 identify Loimia macrobranchia sp. n. by its long length of $360 \mathrm{~mm}$ (L. borealis sp. n. $84 \mathrm{~mm} ; L$. 
297 ingens $5 \mathrm{~mm}$; L. bandera $30 \mathrm{~mm}$; L. arborea $120 \mathrm{~mm}$ ). The largest species within this genus is 298 Loimia ramzega Lavesque, Bonifácio, Londoño-Mesa, Le Garrec \& Grall, 2017 from French 299 waters (maximum length, $650 \mathrm{~mm}$ ), and it differs from L. macrobranchia sp. $\mathrm{n}$. in the shape of 300 its first pair of branchiae, with a thick main stem and many dendritic branches arranged in five 301 levels (Lavesque et al., 2017).

302 Etymology. We attribute to this taxon the epithet "macrobranchia" to indicate the first pair of 303 large branchiae.

304 Type locality: Guaishitan Beach, Fangchenggang City, Guangxi province, China $\left(21^{\circ} 30^{\prime} 4.44^{\prime \prime} \mathrm{N}\right.$ $\left.305108^{\circ} 12^{\prime} 59.81^{\prime \prime} \mathrm{E}\right)$.

306 Distribution: China, Guangxi Province.

307 Phylogenetic analysis

308 Kimura's two-parameter pairwise genetic distance between $L$. arborea from this study and 309 that from GenBank (Carr et al., 2011) was 32.1\%, suggesting that they are different species. The 310 genetic distance between Loimia sp. from India and that from Thailand was $0.6 \%$, indicating that 311 they are identical species. Except for Loimia sp. and L. arborea, the mean sequence divergences 312 within species ranged from $0.0 \%$ (L. bandera and L. ramzega) to $0.4 \%$ (L. macrobranchia sp. $313 \mathrm{n}$.), and the mean sequence divergences between species, excluding the outgroups, ranged from $31415.4 \%$ (L. ingens and Loimia sp.) to $30.2 \%$ (L. arborea from GenBank and L. ingens). The 315 highest divergence between Loimia species and the outgroups was $29.8 \%$ (L. borealis $\mathrm{sp}$. $\mathrm{n}$. and 316 T. lapidaria).

317 The combined phylogenetic trees (Fig. 9) reconstructed from both maximum likelihoods 318 (ML) and Bayesian inference (BI) analyses were generally comparable, and all ingroup taxa 319 were recovered in a clade with high support value (BP [maximum likelihood bootstrap 320 percentage] $>99 \%$, PP [Bayesian posterior probability] = 1.0). Loimia arborea, whose sequence 321 was downloaded from GenBank (Carr et al., 2011), clustered together with the outgroups (T. 322 lapidaria and P. cristata) with moderately high support ( $\mathrm{BP}=73, \mathrm{PP}=0.99)$. In addition, the 323 average genetic divergence between $L$. arborea species from GenBank and other $L$. arborea 324 species from this study was $32.1 \%$, indicating that they are different species.

325 Phylogenetic tree reconstruction of the COI gene showed two well supported main clades 326 (Fig. 9, clades A, B) with moderately high support $(\mathrm{BP}=73, \mathrm{PP}=0.99)$. Clade A included $L$. 327 ingens from China, Loimia sp. from Thailand and India, L. medusa from the USA, and $L$. 
328

329

330

331

332

333

334

335

336

337

338

339

340

341

342

343

344

345

346

347

348

349

350

351

352

353

354

355

356

357

358

ramzega from France. Loimia ingens and Loimia sp. formed a highly supported clade (BP = 89, $\mathrm{PP}=1.0$ ), indicating their close relationship. Clade B grouped L. macrobranchia sp. n., L. arborea, L. bandera, and L. borealis sp. n. (Fig. 9). Loimia arborea and L. bandera formed a strongly supported subclade $(\mathrm{BP}=97, \mathrm{PP}=1.00)$, illustrating that they are more genetically related than the rest of the species within clade B.

\section{Discussion}

We re-identified the specimens deposited in the MBMCAS under the name L. medusa and collected new specimens near their recorded sites. This analysis revealed that the specimens belonged to two different species, both new and significantly different from L. medusa as described by Hutchings \& Glasby (1988). One species, L. borealis sp. n., was collected from the Shandong Peninsula. It differed from L. medusa by the presence of large round lobes on segment 3 and compact long rectangular mid-ventral shields (Table 4). The other species, $L$.

macrobranchia sp. n., was identified in Guangxi Province. Similar to L. medusa, the first pair of branchiae were approximately three times longer than the body width. However, L. medusa had eyespots arranged in small groups on each side of the posterior prostomium, which were absent in L. macrobranchia sp. n. (Table 4). Hutchings \& Glasby (1995) designated a neotype for Loimia medusa and indicated that their distribution was restricted to the Arabian Sea. Due to the

long distance between China and the type locality (Red Sea, neotype from the Persian Gulf) of $L$. medusa, we believe that the older records of L. medusa in China are misidentifications and this species does not occur in Chinese seas.

According to Carrerette \& Nogueira (2015), Loimia montagui was initially identified as Terebella montagui from the Philippines by Grube (1878), and then assigned to the genus Loimia by Hartman (1959). Subsequently, Terebella montagui Grube, 1878 was redefined as Loimia grubei by Holthe (1986). Presently, the taxonomic significance of Loimia montagui (Grube, 1878) in WoRMS (http://www.marinespecies.org) is uncertain. Given the brief descriptions of L. grubei by Holthe (1986) and L. montagui by Hartman (1959), we referred to the descriptions of L. grubei by Carrerette \& Nogueira (2015) and L. montagui by Caullery (1944). According to these descriptions, the species has a pair of round lateral lobes on segment 1, slightly shorter round lobes on segment 3 , branchiae with short branchial filaments branching dichotomously from the secondary stems that originate from the short main stem, and ventral shields extending from segments 2 to 14 (Table 4). By contrast, L. borealis sp. n. has large 
359

360

361

362

363

364

365

366

367

368

369

370

371

372

373

374

375

376

377

378

379

380

381

382

383

384

385

386

387

388

389

ventral lateral lobes on segment 1, well-developed lobes on segment 3 that are slightly larger than those on segment 1, and seven mid-ventral shields from segments 2 to 10 (Fig. 2B, C). As for L. macrobranchia sp. n., the lobes on segment 1 are long, and they extend as elevated collars that connect mid-ventrally (Fig. 6C, D). In addition, 10 ventral shields from segments 2 to 12 are present. Previously, Hutchings \& Glasby (1988) examined materials collected from Australia that were initially identified as $L$. montagui. Subsequently, they classified these specimens as $L$. ingens. As for the materials collected from coastal areas of Chinese seas and identified as $L$. ingens, they differed from L. montagui in the shape of their branchiae, namely in their long basal stems, subdistal dendritic branches, and loose spiral filaments (Fig. 5I).

Carrerette \& Nogueira (2015) suggested that the shape and position of the lobes on segments 1 and 3, the shape of the ventral glandular shields, and the number of segments on which they are present, together with the number and general morphology of the uncinial teeth, are critical in the identification of Loimia species. As observed by us, the shape and distribution of mid-ventral shields, which have rarely been included in species descriptions (Carrerette \& Nogueria, 2015), are useful characteristics in the taxonomic classification of Loimia species. The mid-ventral shield shape of Loimia species varies from rectangular to trapezoidal, which is typical of Terebellidae (Nogueira, Hutchings \& Fukuda, 2010; Nogueira, Fitzhugh \& Hutchings, 2013). These shields usually extend from anterior segments to posterior segments where notopodia terminate, appearing blood red-to-yellowish in live materials (Figs 1C, 5A, G, 6A) and pale yellow-to-white in preserved specimens (Fig. 5B). Londoño-Mesa $(2006,2009)$ and Londoño-Mesa \& Carrera-Parra (2005) commented on the usefulness of the distribution of ventral shields as a specific characteristic for Loimia species, although it is difficult to determine the exact anterior segment (mostly short and fused to each other) on which the shields begin, and the particular segment on which they end. Carrerette \& Nogueria (2015) also mentioned that differences in the shape of shields was an additional useful characteristic in the identification Loimia species.

After re-identifying the specimens that have been deposited in the MBMCAS for many decades, we found that the important morphological characteristics of branchiae and lobes were destroyed, and their shape was undefinable (Figs 2D-F, 6F, G). By contrast, the characteristics of mid-ventral shields were well preserved, and they were easily recognizable. Equally-sized midventral shields in $L$. borealis sp. $\mathrm{n}$. spanned from segments 2 to 10 , each with a length 
390 significantly longer than the width (Fig. 2D-F). In old materials of L. macrobranchia sp. n. and

391 L. ingens, the rectangular ventral shields spanned from segments 2 to 12 (Fig. 6F-G), similar to

392 the shields in new materials. In agreement with Carrerette \& Nogueria (2015), we conclude that

393 the shape of mid-ventral shields is a significant character for the identification of species of

394 Loimia.

395 In the phylogenetic tree (Fig. 9), Loimia macrobranchia sp. n. was recovered as a

396 monophyletic clade, although nodal support was low. Loimia borealis sp. n. was retrieved as a

397 sister to the clades of L. arborea and L. bandera with moderate support (Fig. 9). In addition,

398 Kimura's two-parameter pairwise genetic distance between L. macrobranchia sp. n. and other

399 Loimia species ranged from $18 \%$ to $24 \%$, and the genetic distance between L. borealis $\mathrm{sp}$. n. and

400 other species ranged from $20 \%$ to $24 \%$, indicating genetic divergences between new species and 401 other Loimia species.

\section{Conclusions}

403 This study is the first to analyze molecular sequence data of Loimia species from Chinese 404 seas. The new species L. borealis sp. n. and L. macrobranchia sp. n. were established based on 405 their morphological and molecular findings. Loimia borealis sp. $\mathrm{n}$. is distinguished from other 406 valid Loimia species by its compact, slender, and rectangular ventral shields, which indicates that 407 the ventral shield shape is a significant characteristic in the identification of Loimia species. The 408 other species, L. macrobranchia sp. n., is characterized by its large size and large first pair of 409 branchiae. A revision of the genus Loimia from Chinese seas was made, and we suspect that 410 older records of L. medusa and L. montagui in China are misidentifications. A key for the 411 identification of Loimia species in Chinese seas is provided. This key only contains valid species 412 listed in WoRMS (http://www.marinespecies.org).

\section{Key to the species of Loimia found in China seas}

414 1. First pair of branchiae three to five times longer than the second and third pairs L. macrobranchia sp. n.

416 -First pair of branchiae equal or slightly longer than the second and third 417 pairs. 2

418 2. Lobes of segment 3 small and rectangular, dorsum with rounded glandular tubercles run 419 together into a low longitudinal ridge on the first 10 anterior segments each side just beside the 420 notopodia. 
421 -Lobes of segment 3 large and semicircular, dorsum without glandular and longitudinal ridge

422

423 3. Lateral lobes on segments 2 partly fused with segment 3

424 -Lateral lobes on segments 2, 3 and 4

five times the width square

\section{Acknowledgements} Qingdao) for their kind help with photographing the specimens.

\section{References} polychaetes. PLoS ONE 6(7), e22232. morphological characters of the genus. Zootaxa 3999, 1-31. 1899-1900 XXIV 2 bis: 1-204. throughput. Nucleic Acids Research 32, 1792-7.

4. Eyespot absent; mid-ventral shields all equal-sized, anterior shields rectangular, with length L. borealis sp. $\mathrm{n}$.

- Red or black eyespots, if present, on basal part of prostomium; nine mid-ventral shields gradually taper, anterior shields rectangular with length two times the width, then trapezoidal or

L. ingens

We are grateful to Dr. Xinming Liu (Institute of Oceanology, Chinese Academy of

Sciences, Qingdao) and Dr. Dong Dong (Institute of Oceanology, Chinese Academy of Sciences,

Carr CM, Hardy SM, Brown TM, Macdonald TA, Hebert PDN, Badger JH. 2011. A tri-oceanic perspective: DNA barcoding reveals geographic structure and cryptic diversity in Canadian

Carrerette O, Nogueira JMM. 2015. The genus Loimia Malmgren, 1866 (Annelida: Terebellidae) off the Brazilian coast, with description of three new species and notes on some

Castresana J. 2000. Selection of conserved blocks from multiple alignments for their use in phylogenetic analysis. Molecular Biology and Evolution 17, 540-552.

Caullery M. 1944. Polychètes Sédentaires de l'Expédition du Siboga: Ariciidae, Spionidae, Chaetopteridae, Chlorhaemidae, Opheliidae, Oweniidae, Sabellariidae, Sternaspidae, Amphictenidae, Ampharetidae, Terebellidae. Siboga-Expeditie Uitkomsten op Zoologisch, Bonatisch. Oceanographisch en Geologisch gebied verzameld in Nederlandsch Oost-Indië

Colgan DJ, Hutchings PA, Brown S. 2001. Phylogenetic relationships within the Terebellomorpha. Journal of the Marine Biological Association of the UK 81(05), 765.

Edgar RC. 2004. MUSCLE: multiple sequence alignment with high accuracy and high 
452 Eilertsen MH, Kongsrud JA, Alvestad T, Stiller J, Rouse GW, Rapp HT. 2017. Do ampharetids 453 take sedimented steps between vents and seeps? Phylogeny and habitat-use of 454 Ampharetidae (Annelida, Terebelliformia) in chemosynthesis-based ecosystems. BMC $455 \quad$ Evolutionary Biology 17(1), 222.

456 Fauchald K, Jumars PA. 1979. The diet of worms: a study of polychaete feeding guilds. Annual 457 Review of Oceanography and Marine Biology 17, 193 - 284.

458 Folmer O, Black M, Hoeh W. 1994. DNA primers for amplification of mitochondrial 459 460 461 462 463 464 465 466 467 468

469 Holthe T. 1986. Evolution, systematics, and distribution of the Polychaeta Terebellomorpha, $470 \quad$ with a catalogue of the taxa and a bibliography. Gunneria 55, 1-236. cytochrome c oxidase subunit I from diverse metazoan invertebrates. Molecular Marine 60 Biology \& Biotechnology 3, 294-9.

Grube AE. 1878. Annulata Semperiana. Beiträge zur Kenntniss der Annelidenfauna der Philippinen. Memoires de L'Academie Imperiale des Sciences de St.Petersbourg, Series 7 , $25(8), 1-300$.

Hartman O. 1959. Catalogue of the polychaetous annelids of the world. Part II. Occasional Papers of the Allan Hancock Foundation 23, 355-628.

Hoang DT, Chernomor O, Haeseler A, Minh BQ, Vinh LS. 2018. UFBoot2: Improving the 67 ultrafast bootstrap approximation. Molecular Biology Evolution 35:518-522.

68 DOI: $10.1093 / \mathrm{molbev} / \mathrm{msx} 281$

Huelsenbeck JP, Ronquist F. 2001. MRBAYES: Bayesian inference of phylogeny.

473 Hutchings PA, Glasby CJ. 1988. The Amphitritinae (Polychaeta: Terebellidae) from Australia. 474 Records of the Australian Museum 40,1-60.

475 Hutchings PA, Glasby CJ. 1995. Description of the widely reported terebellid polychaetes $476 \quad$ Loimia medusa (Savigny) and Amphitrite rubra (Risso). Mitteilungen aus dem 477 Hamburgischen Zoologischen Museum und Institut 92, 149-154.

478 Hutchings PA. 1990. Terebellidae (Polychaeta) from the Hong Kong region. In: Morton, B. 479 (Ed.), Proceedings of the Second International Marine Biological Workshop: The Marine $480 \quad$ Flora and Fauna of Hong Kong and Southern China. Hong Kong University Press, Hong $481 \quad$ Kong, pp. 379-412. 
482 Hutchings PA. 1997. The Terebellidae from the Wallabi Group, Houtman Abrolhos Islands, 483 Western Australia. In: Wells, F.E. (Ed.), The Marine Flora and Fauna of the Houtman 484 Abrolhos Islands, Western Australia. Western Australian Museum, Perth, pp. 459-501. 485 Hutchings PA, Nogueira JMN, Carrerette O. 2017. Terebellidae Johnston, 1846. In: Schmidt-

486

487

488

489

490

491

492

493

494

495

496

497

498

499

500

501

502

503

504

505

506

507

508

509

510

511

512

Rhaesa, Andreas Hrsg. v. Beutel RG, Glaubrecht M, Kristensen NP, Prendini L, Purschke

G, Richter S, Westheide W, Leschen R (Eds) A Natural History of the Phyla of the Animal Kingdom. Handbook of Zoology, 1-64.

Johnston G. 1846. An index to the British Annelides. Annals and Magazine of Natural History 1(16): 433-462. https://doi.org/10.1080/037454809495980

Jumars PA, Dorgan KM, Lindsay SM. 2015. Diet of worms emended: an update of polychaete feeding guilds Annual Review of Marine Science 7:497-520. DOI: 10.1146/annurevmarine-010814-020007.

Kalyaanamoorthy S, Minh BQ, Wong TKF, Haeseler A, Jermiin LS. 2017. ModelFinder: fast model selection for accurate phylogenetic estimates. Nature Methods 14:587-589. DOI:10.1038/nmeth.4285

Kumar S, Stecher G, Tamura K. 2016. MEGA7: molecular evolutionary genetics analysis version 7.0 for bigger datasets. Molecular Biology and Evolution 33(7):1870-1874. DOI: 10.1093/molbev/msw054.

Lavesque N, Bonifácio P, Londoño-Mesa MH, Le Garrec V, Grall J. 2017. Loimia ramzega sp. nov. a new giant species of Terebellidae (Polychaeta) from French waters (Brittany English Channel). Journal of the Marine Biological Association of the United Kingdom 97(05), 935942.

Linnaeus C. 1767. Systema naturae per regna tria naturae: secundum classes, ordines, genera, species, cum characteribus, differentiis, synonymis, locis. Ed. 12. 1., Regnum Animale. 1 \& 2. Holmiae, Laurentii Salvii. Holmiae [Stockholm], Laurentii Salvii. pp. 1-532 [1766] pp. 533-1327 [1767]. available at http://www.biodiversitylibrary.org/item/83650\#5

Liu JY. 2008. Checklist of marine biota of China seas. China Science Press. 1267 pp.

Londoño -Mesa MH, Carrera-Parra LF. 2005. Terebellidae (Polychaeta) from the Mexican Caribbean with description of four new species. Zootaxa 1057, 1-44.

Londoño-Mesa MH. 2006. Revision of Paraeupolymnia, and redescription of Nicolea uspiana comb. nov. (Terebellidae: Polychaeta). Zootaxa, 1117, 21-35.

Peerj reviewing PDF | (2019:12:43931:3:0:NEW 3 Jun 2020) 
513 Londoño-Mesa MH. 2009. Terebellidae (Polychaeta: Terebellida) from the Grand Caribbean 514 region. Zootaxa 2320, 1-93.

515 Malmgren, Anders Johan. 1866. Nordiska Hafs-Annulater. Öfversigt af Königlich

516 Vetenskapsakademiens förhandlingar, Stockholm. 22(5): 355-410, plates XVIII-XXIX., 517 available online at https://biodiversitylibrary.org/page/32339631page(s): 380

518 Moore JP. 1903. Polychaeta from the coastal slope of Japan and from Kamchatka and Bering 519 Sea. Proceedings of the Academy of Natural Sciences of Philadelphia 55: 401-490, plates 520 XXIII-XXVII.

521 Müller OF. 1776. Zoologiæ Danicæ Prodromus, seu Animalium Daniæ et Norvegiæ indigenarum 522 characteres, nomina, et synonyma imprimis popularium. Havnice [Copenhagen]: Hallageri. $523 \quad$ xxxii +274 pp. available at http://www.biodiversitylibrary.org/item/47550

524 Nguyen LT, Schmidt HA, Haeseler A, Minh BQ. 2015. IQ-TREE: A fast and effective stochastic 525 algorithm for estimating maximum likelihood phylogenies. Molecular Biology and 526 Evolution 32:268-274. DOI: 10.1093/molbev/msu300

527 Nogueira JMM, Hutchings PA, Fukuda MV. 2010. Morphology of terebelliform polychaetes 528 (Annelida: Polychaeta: Terebelliformia), with a focus on Terebellidae. Zootaxa 2460, 1 $529 \quad 185$.

530 Nogueira JMM, Fitzhugh K, Hutchings P. 2013. The continuing challenge of phylogenetic 531 relationships in Terebelliformia (Annelida: Polychaeta). Invertebrate Systematics 27, 186532238.

533 Nogueira JMM, Hutchings P, Carrerette O. 2015. Terebellidae (Annelida, Terebelliformia) from 534 Lizard Island, Great Barrier Reef, Australia. Zootaxa 4019, 484-576.

535 Rouse GW, Pleijel F. 2001. Polychaetes. Oxford: Oxford University Press.

536 Savigny JS. 1818. Section on Annelida in Lamarck, J.B. de 1818. Histoire Naturelle des 537 Animaux sans Vertèbres 5, 1-618.

538 Siddall ME, Apakupakul K, Burreson EM, Coates KA, Erseus C, Gelder SR, Kallersjo M, 539 Trapido-Rosenthal H. 2001. Validating Livanow: molecular data agree that leeches, 540 Branchiobdellidans, and Acanthobdella peledina form a monophyletic group of 541 oligochaetes. Molecular Phylogenetics \& Evolution 21 (3), 346-351.

542 DOI:10.1006/mpev.2001.1021, available online at http://www.idealibrary.com 
543 Stiller J, Rousset V, Pleijel F, Chevaldonné, Pierre, Vrijenhoek RC, Rouse GW. 2013.

544 Phylogeny, biogeography and systematics of hydrothermal vent and methane seep 545 Amphisamytha (Ampharetidae, Annelida), with descriptions of three new species.

$546 \quad$ Systematics and Biodiversity 11(1), 35-65. 


\section{Figure 1}

Live specimens of Loimia borealis sp. $\mathrm{n}$.

(A, D) Paratype, MBM286591; (B-C) paratype, MBM286593. (A) Dorsal view; (B) ventro-lateral view; (C) detail of the anterior part, ventro-lateral view; (D) anterior part, detail of the branchiae, dorsal view. Scales: (A-B) 10mm; (C-D) $5 \mathrm{~mm}$.
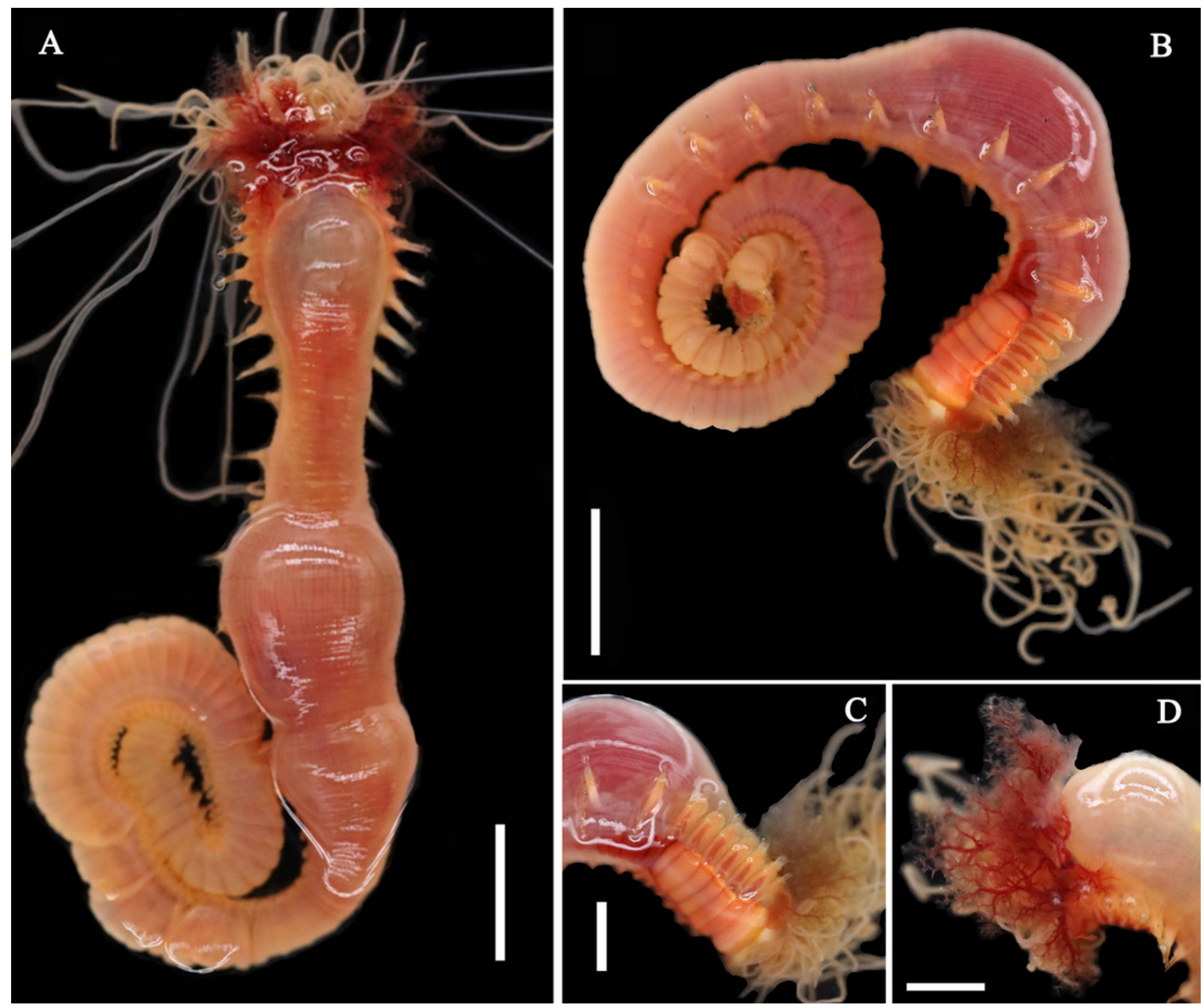


\section{Figure 2}

Details of Loimia borealis sp. $\mathrm{n}$.

(A-C) Holotype, MBM286585; (D-F) specimen, MBM199302. (A) Anterior part, dorsal view; (B) anterior part, lateral view; (C) anterior part, ventral view, detail of ventral shields; (D) anterior part, dorsal view; (E) anterior part, lateral view; (F) anterior part, ventral view, detail of ventral shields. Numbers refer to segments; br1, br2, br3 refer to the three pairs of branchiae; arrows point to nephridial papillae. Abbreviations: $\|=$ lower lip, $u l=$ upper lip, br $=$ branchiae. Scale: $2 \mathrm{~mm}$. 


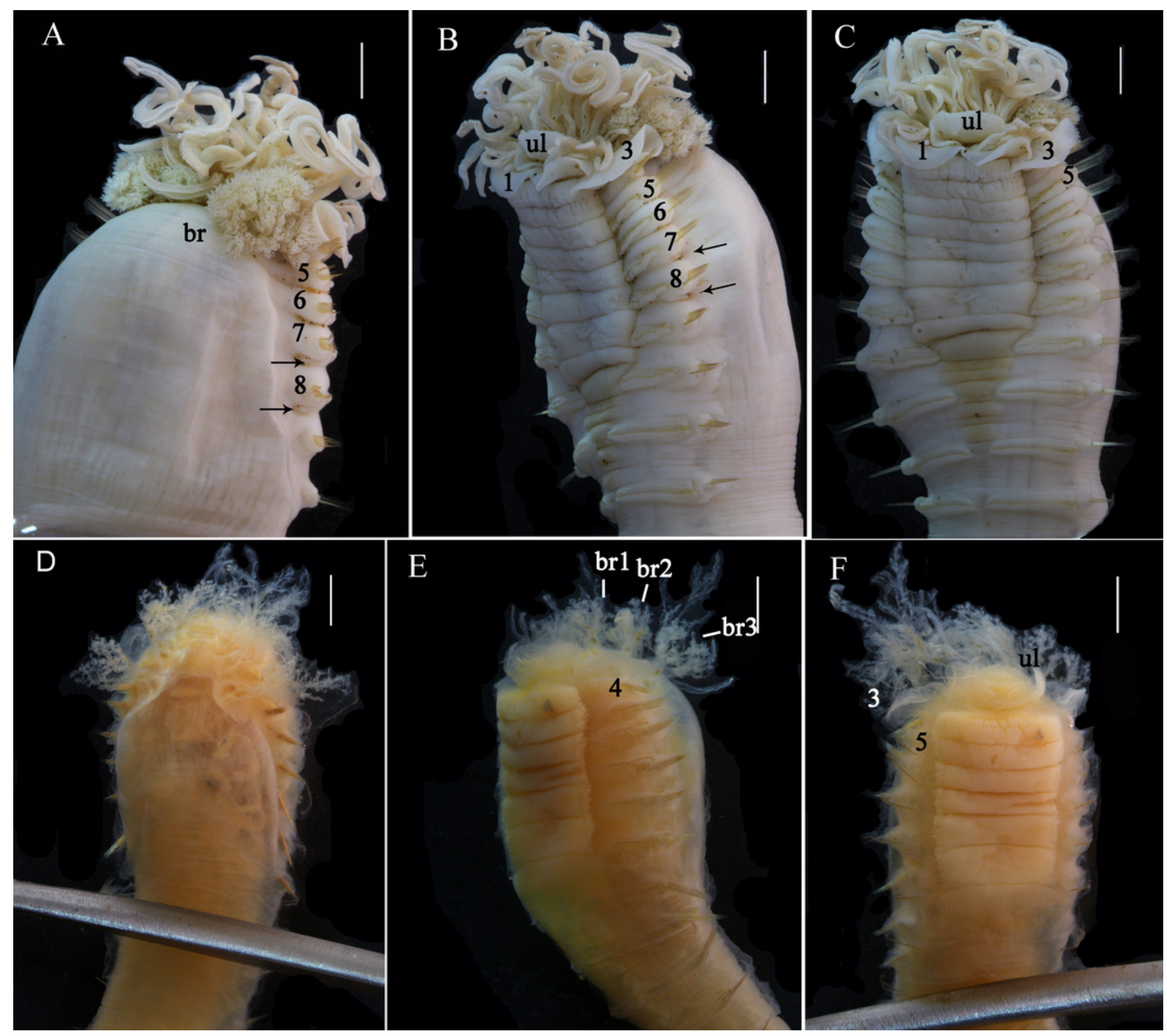




\section{Figure 3}

Details of Loimia borealis sp. n. under SEM. (Paratype, MBM286592)

(A) Anterior part, ventral view; (B) anterior segments, lobes on segments 1 and 3, ventral view; (C) detail of the lobe on segment 3, lateral view; (D) notopodium from segment 18; (E) notochaetae from segment 5; (F) notochaetae from segment 12; $(\mathrm{G})$ uncini from posterior segment; $(\mathrm{H})$ uncini from segment 12, double rows of uncini; (I) uncini from an anterior segment; (J) uncini from an anterior segment; (K) notochaetae from segment 9; (L) notopodium from segment 8 . Numbers refer to segments. Abbreviations: $u l=$ upper lip.

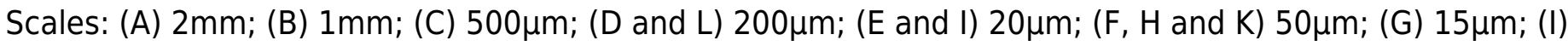
$30 \mu \mathrm{m}$.
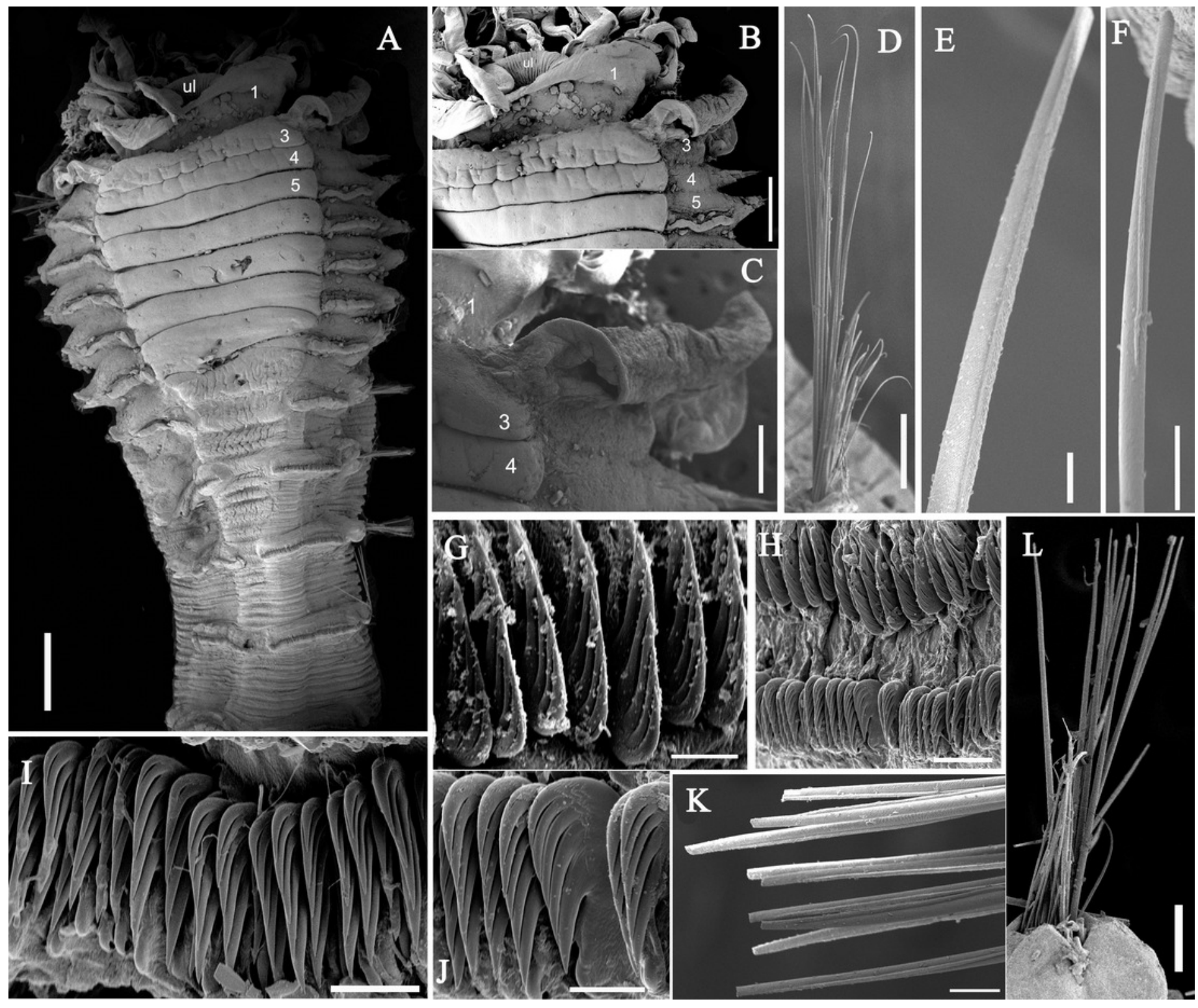


\section{Figure 4}

Uncini and notochaetae of Loimia borealis sp. n.(Holotype, MBM286585)

(A) Uncini, segment 20, double rows of uncini; (B) uncini, segment 6; (C) uncini, segment 95;

(D) uncini, segment 21; (E) notochaetae, segment 18; (F) notopodium of the segment 8; (G) uncini, segment $5 ;(\mathrm{H})$ notochaetae, segment 7 ; (I) notopodium of the segment 7 ; $(\mathrm{J})$

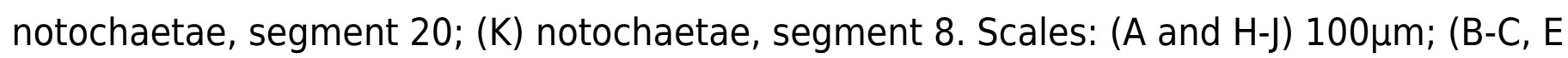
and K) $50 \mu \mathrm{m} ;(\mathrm{D}, \mathrm{G}) 20 \mu \mathrm{m} ;(\mathrm{F}) 200 \mu \mathrm{m}$. 


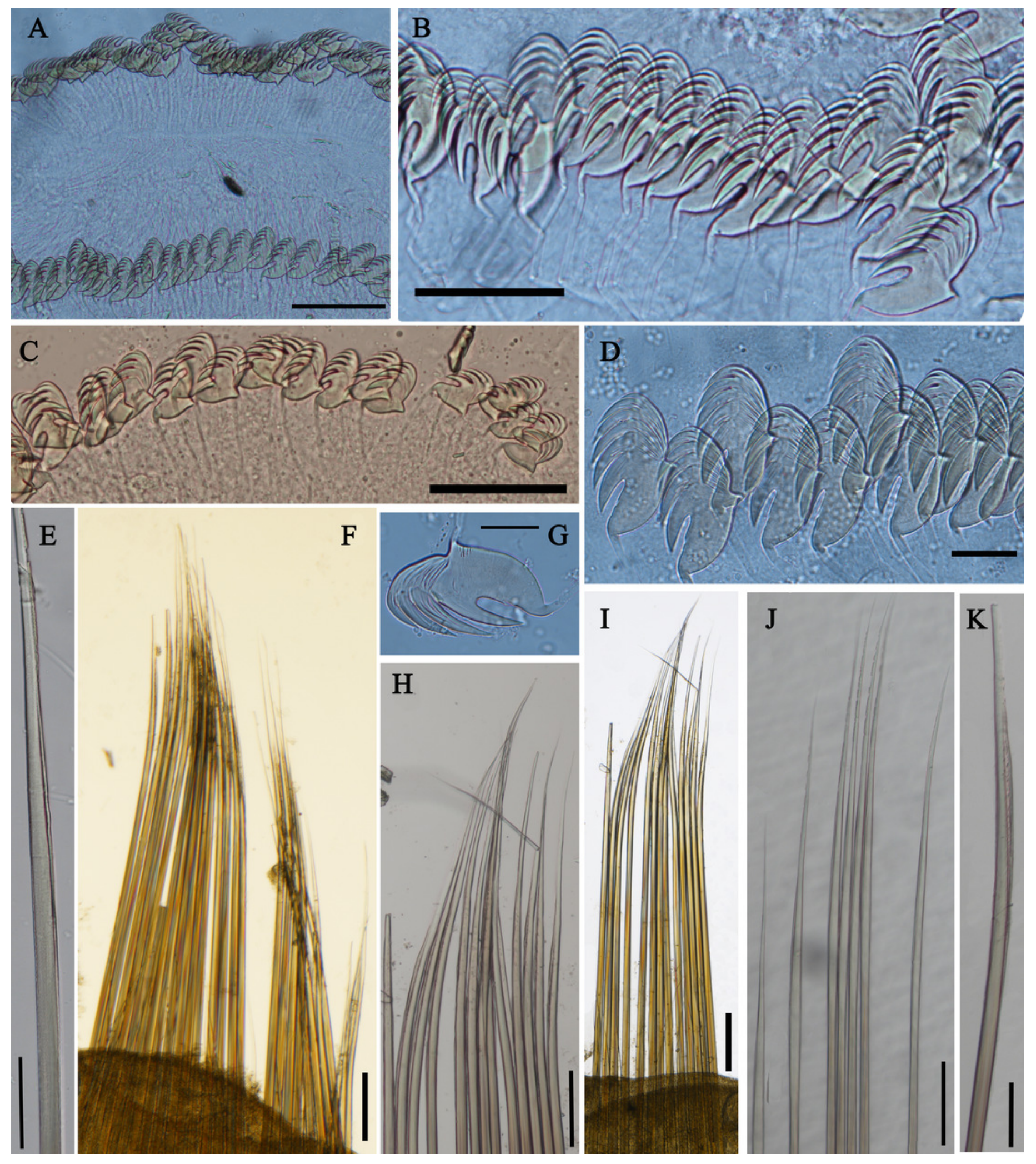




\section{Figure 5}

Photographs of Loimia arborea, Loimia bandera and Loimia ingens.

(A) Loimia arborea, MBM286581, specimen in life; (B-D) Loimia arborea, MBM286582; (E-F) Loimia bandera, MBM286594; (G) Loimia ingens, MBM286598; (H-I) Loimia ingens, MBM286600. (A) Posterior part lost, vento-lateral view; (B) complete, dorsal-lateral view; (C) anterior part, ventral view; (D) anterior part, detail of the glandular ridge, dorsal view; (E) posterior part lost, lateral view; (F) anterior part, detail of the glandular ridge, dorsal view; (G) live specimen, ventro-lateral view; (H) incomplete, ventral view; (I) incomplete, dorsal view; (J) anterior part, lobes on anterior segments, tentacles with brown transverse bands, ventral view. Numbers refer to segments. Abbreviations: $\mathrm{ul}=$ upper lip. Scales: $(\mathrm{A}-\mathrm{C}$ and $\mathrm{E}-\mathrm{F})$ $1 \mathrm{~cm}$; (D) $500 \mathrm{~mm}$; (G-I) $2 \mathrm{~mm}$; (J) $1 \mathrm{~mm}$. 

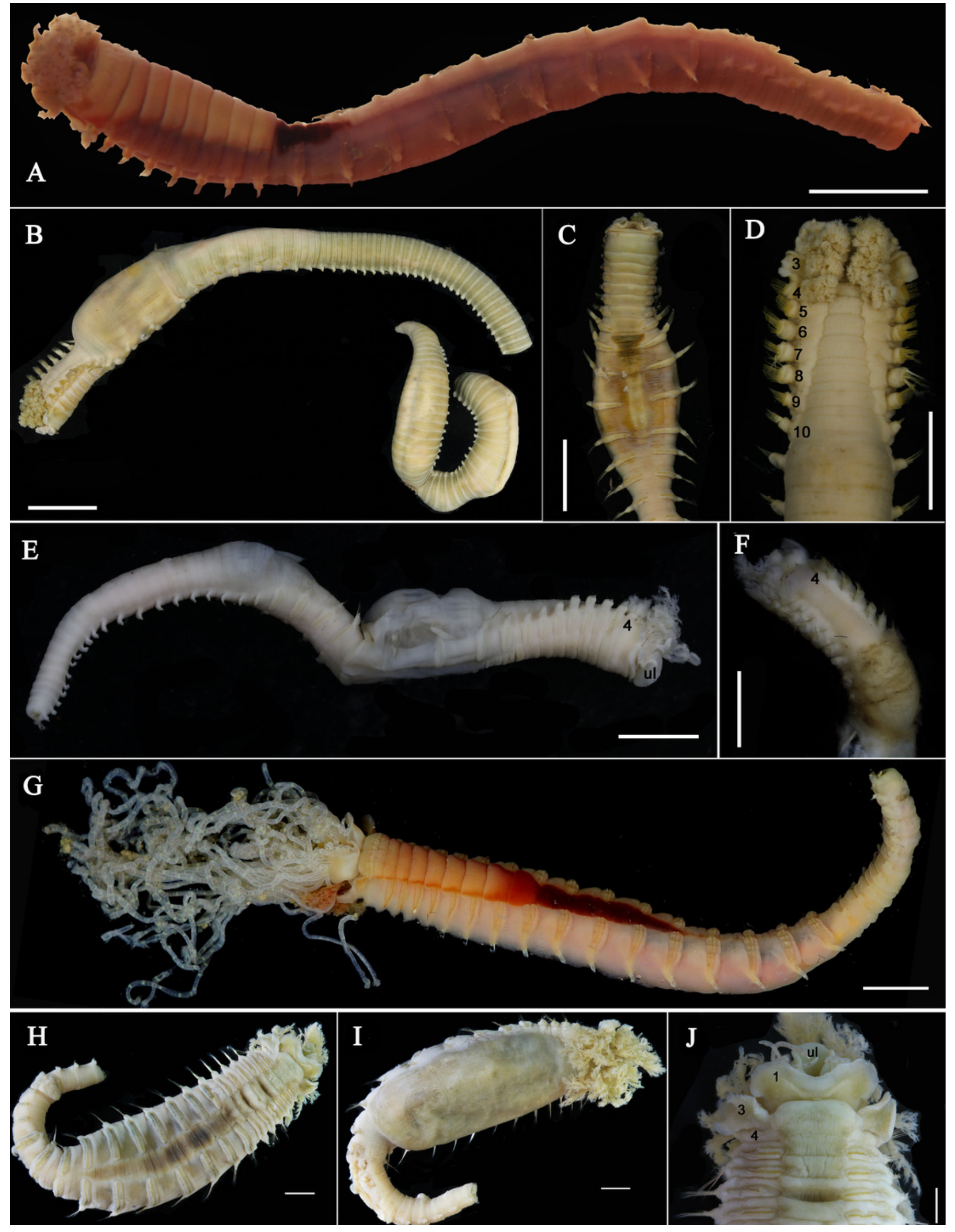


\section{Figure 6}

Photographs of Loimia macrobranchia sp. n.

(A-E) Holotype, MBM286579; (F-G) specimen, MBM199304. (A) Complete animal, alive, ventral view; (B) anterior part, dorsal view; (C) anterior part, lateral view; (D) anterior part, ventral view; (E) anterior part, lateral view, detail of branchiae; $(F)$ anterior part, lateral view; (G) anterior part, ventral view, detail of ventral shields. Numbers refer to segments; br1, br2, br3 refer to three pairs of branchiae; unspecified arrows point to nephridial papillae. Abbreviations: $\mathrm{ul}=$ upper lip. Scales: (A) $1 \mathrm{~cm}$; (B-G) $2 \mathrm{~mm}$. 


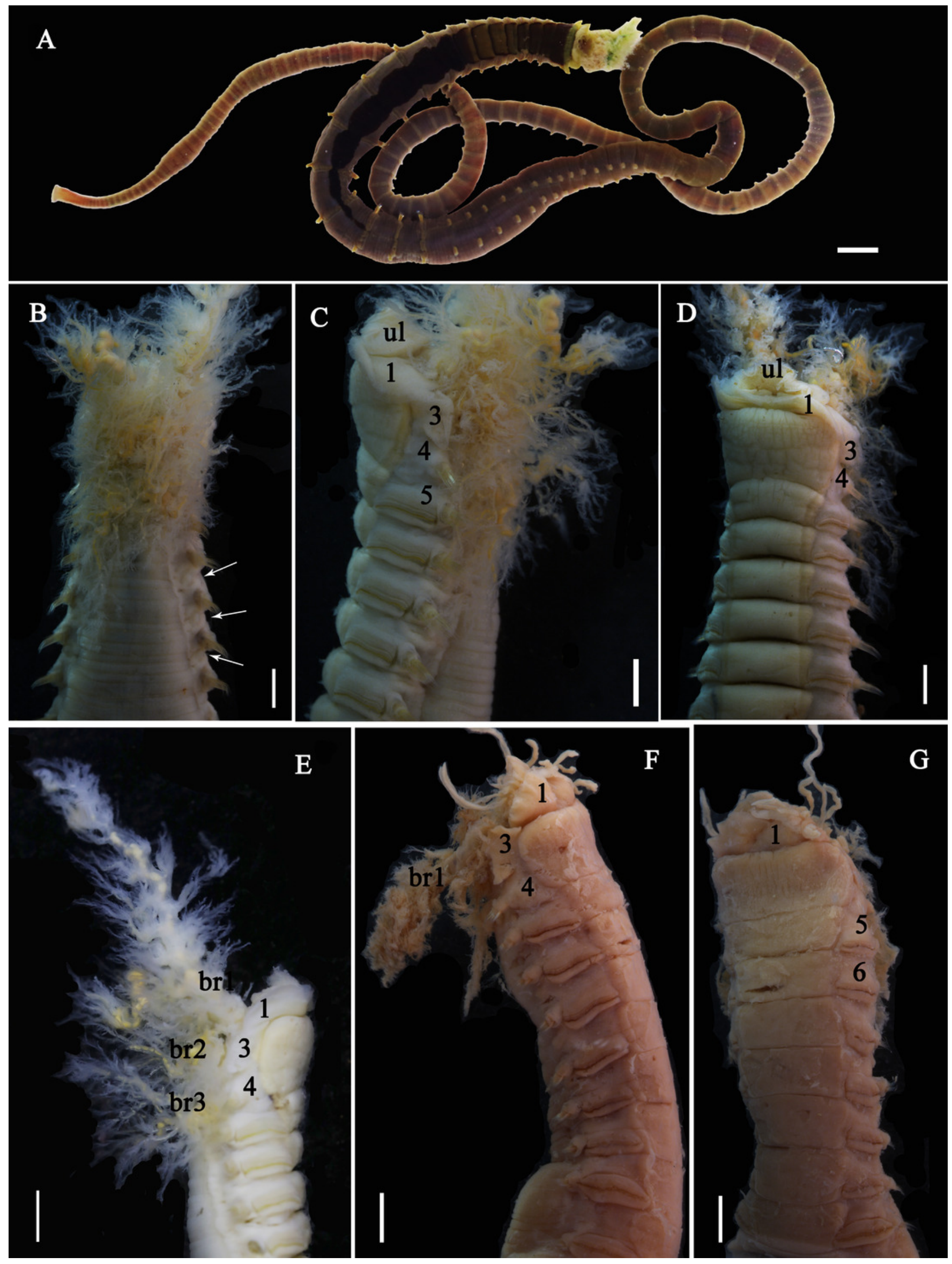




\section{Figure 7}

Uncini and notochaetae of Loimia macrobranchia sp. n. (Holotype, MBM286579)

(A) Notopodium of the segment 8; (B) notochaetae, segment 5; (C) notochaetae, segment 6;

(D) notopodium of the segment 18; (E) notochaetae from segment 18; $(F)$ notochaetae from segment 11; (G) uncini, segment 21; (H) uncini, segment 5; (I) uncini, segment 15; (J) uncini,

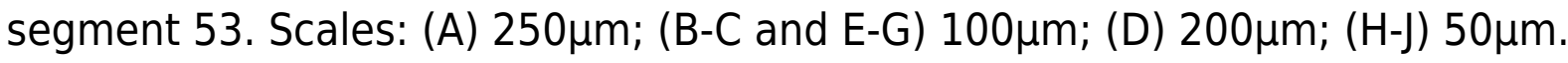

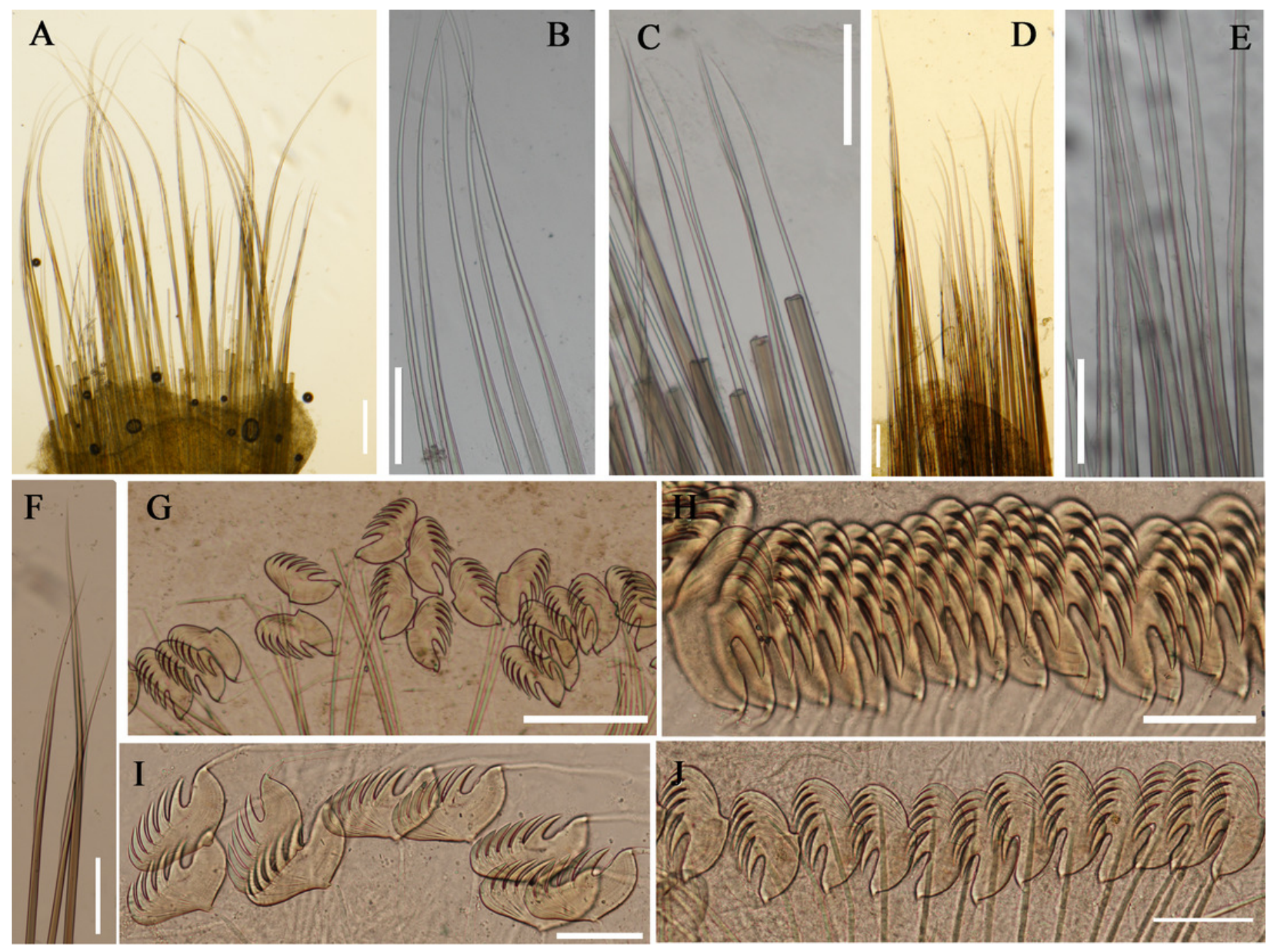


Figure 8

Uncini and notochaetae of Loimia macrobranchia sp. n. under SEM. (Holotype, MBM286579)

(A) Notopodium from segment 6; (B) notochaetae from segment 18; (C) uncini, segment 17, double rows of uncini; (D) notopodium from segment 17; (E) uncini from segment 30; (F)

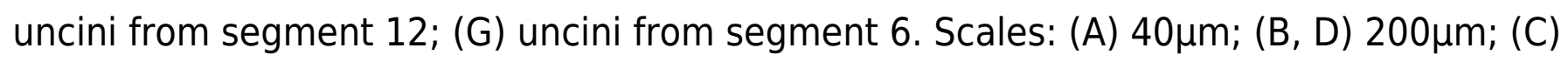
$50 \mu \mathrm{m} ;(\mathrm{E}) 15 \mu \mathrm{m}$; (F) $10 \mu \mathrm{m}$; (G) $20 \mu \mathrm{m}$. 

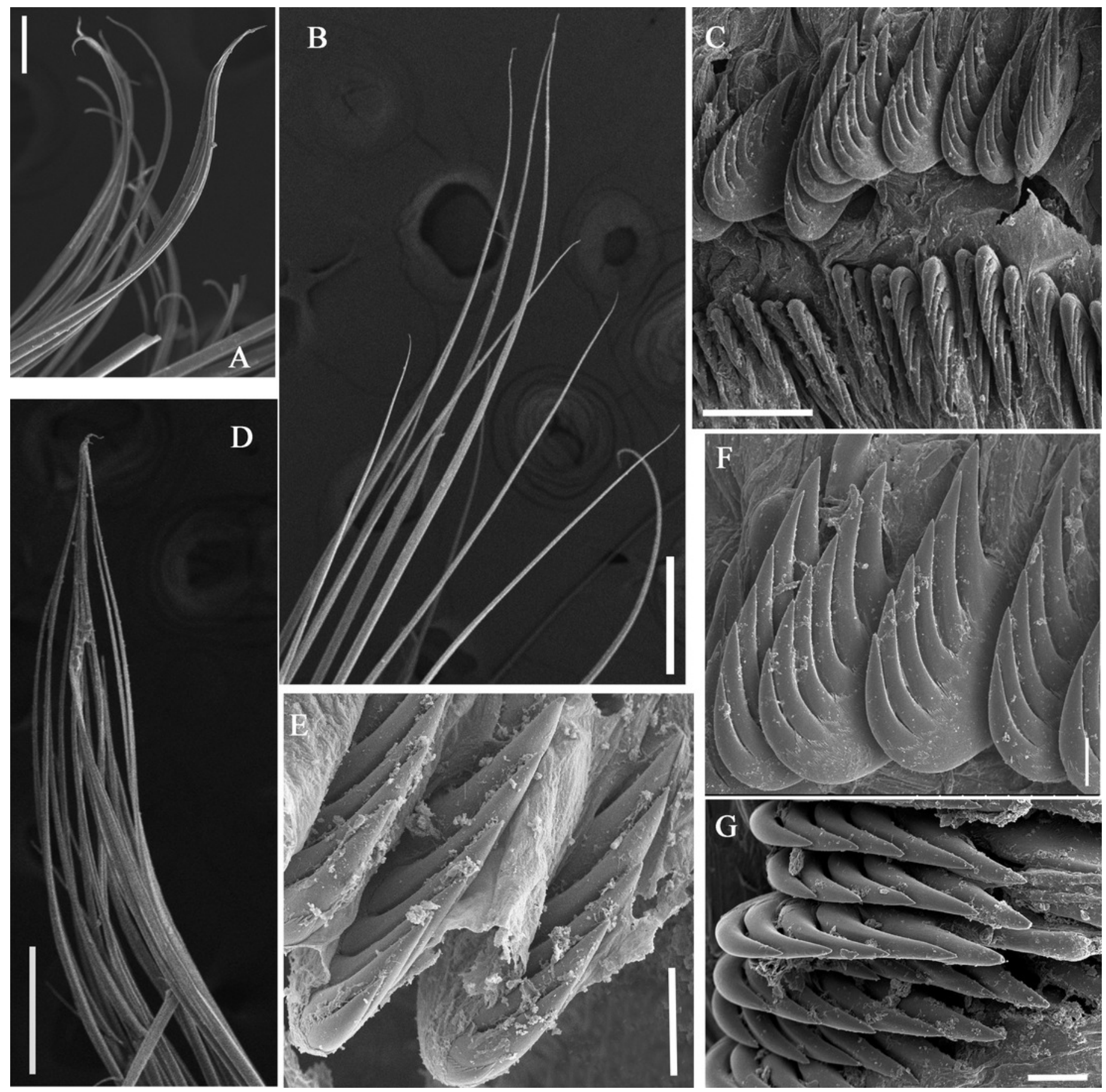
Figure 9

Phylogenetic tree obtained by the Maximum likelihood analysis based on the COI gene sequences.

Maximum likelihood bootstrap scores (BP, left) and Bayesian posterior probabilities (PP, right) are indicated adjacent to each node. Values of BP $\geq 75 \%$ and PP $\geq 0.95$ are marked in bold. Only values of $B P \geq 50 \%$ and $P P \geq 0.5$ are shown. Species names and sequence origins are given next to the corresponding clades. Additional details on the sequences used for this tree are given in Table 2 . Clade annotations $A$ and $B$ are discussed in the text.

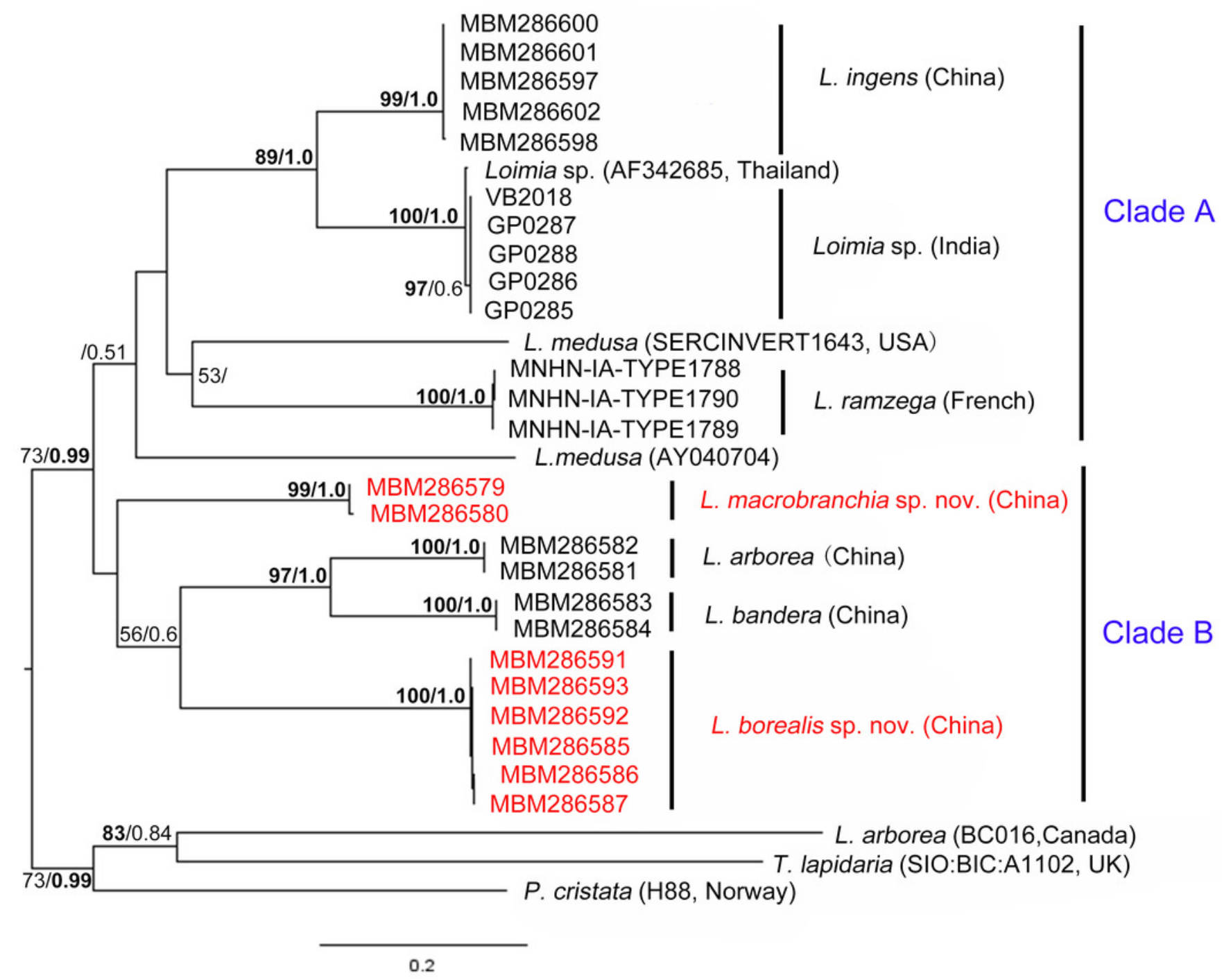




\section{Table 1 (on next page)}

Specimens information.

Species used in the molecular analysis with reference to their voucher ID, specimen location, Genbank accession numbers, GPS coordinates and references. 


\begin{tabular}{|c|c|c|c|c|c|}
\hline Species & Location & Vouchers & $\begin{array}{l}\text { Genbank } \\
\text { accession } \\
\text { number }\end{array}$ & $\begin{array}{l}\text { GPS } \\
\text { coordinates }\end{array}$ & References \\
\hline \multirow[t]{6}{*}{ Loimia borealis sp. $\mathrm{n}$. } & China, Shouguang City & MBM286591 & MN133237 & $37^{\circ} 16^{\prime} 34.00^{\prime \prime} \mathrm{N}$ & This study \\
\hline & & MBM286593 & MN133238 & $119^{\circ} 02^{\prime} 19.44 " \mathrm{E}$ & This study \\
\hline & & MBM286592 & MN133239 & & This study \\
\hline & & MBM286585 & MN133240 & & This study \\
\hline & & MBM286586 & MT246207 & & This study \\
\hline & & MBM286587 & MT246208 & & This study \\
\hline \multirow[t]{2}{*}{ Loimia macrobranchia sp. n. } & China, Fangchenggang City & MBM286579 & MN133241 & $21^{\circ} 30^{\prime} 17.65^{\prime \prime} \mathrm{N}$ & This study \\
\hline & & MBM286580 & MN133242 & $108^{\circ} 13^{\prime} 37.07^{\prime \prime} \mathrm{E}$ & This study \\
\hline \multirow[t]{5}{*}{ Loimia ingens (Grube, 1878) } & China, Linqiangshidao Island & MBM286597 & MN133246 & $21^{\circ} 04^{\prime} 46.46 " \mathrm{~N}$ & This study \\
\hline & & MBM286598 & MN133248 & $109^{\circ} 06^{\prime} 19.97^{\prime \prime} \mathrm{E}$ & This study \\
\hline & China, Weizhoudao Island & MBM286600 & MN133244 & $21^{\circ} 30^{\prime} 17.65^{\prime \prime} \mathrm{N}$ & This study \\
\hline & & MBM286601 & MN133245 & $108^{\circ} 13^{\prime} 37.07^{\prime \prime} \mathrm{E}$ & This study \\
\hline & & MBM286602 & MN133247 & & This study \\
\hline \multirow[t]{6}{*}{ Loimia arborea Moore, 1903} & China, Yellow sea & MBM286582 & MN133249 & $36^{\circ} 59^{\prime} 45.60^{\prime \prime} \mathrm{N}$ & This study \\
\hline & & & & $122^{\circ} 59^{\prime} 31.20^{\prime \prime} \mathrm{E}$ & \\
\hline & & MBM286581 & MN133250 & $30^{\circ} 59^{\prime} 28.59^{\prime \prime} \mathrm{N}$ & This study \\
\hline & & & & $122^{\circ} 20^{\prime} 39.71^{\prime \prime} \mathrm{E}$ & \\
\hline & Canada, British Columbia, & $\mathrm{BC} 016$ & HM473449 & $51^{\circ} 21^{\prime} 36.00^{\prime \prime} \mathrm{N}$ & Carr et al. (2011) \\
\hline & Queen Charlotte Sound & & & $128^{\circ} 35^{\prime} 24.00^{\prime \prime} \mathrm{W}$ & \\
\hline \multirow[t]{2}{*}{ Loimia bandera Hutchings, 1990} & China, Taiwan Strait & MBM286583 & MN133251 & $25^{\circ} 50^{\prime} 26.88^{\prime \prime} \mathrm{N}$ & This study \\
\hline & & MBM286584 & MN133252 & $120^{\circ} 14^{\prime} 50.28^{\prime \prime} \mathrm{E}$ & This study \\
\hline \multirow[t]{3}{*}{ Loimia medusa (Savigny, 1818) } & - & & AY040704 & - & Siddall et al. (2001) \\
\hline & USA, Virginia, Virginia & SERCINVERT1643 & MK308193 & $36^{\circ} 55^{\prime} 21.36^{\prime \prime} \mathrm{N}$ & Direct Submission \\
\hline & Beach County, Lower & & & $76^{\circ} 4^{\prime} 21.36^{\prime \prime} \mathrm{W}$ & \\
\hline
\end{tabular}




\begin{tabular}{|c|c|c|c|c|c|}
\hline Species & Location & Vouchers & $\begin{array}{l}\text { Genbank } \\
\text { accession } \\
\text { number }\end{array}$ & GPS coordinates & References \\
\hline \multirow{6}{*}{$\begin{array}{l}\text { Loimia ramzega Lavesque, Bonifácio, } \\
\text { Londoño-Mesa, Le Garrec \& Grall, } \\
2017\end{array}$} & \multirow{6}{*}{$\begin{array}{l}\text { French, Brittany, English } \\
\text { Channel }\end{array}$} & MNHN-IA- & \multirow[t]{2}{*}{ KY555061 } & $48^{\circ} 37^{\prime} 37.20^{\prime \prime} \mathrm{N}$ & \multirow[t]{6}{*}{ Lavesque et al. (2017) } \\
\hline & & TYPE 1788 & & $4^{\circ} 34^{\prime} 08.50^{\prime \prime} \mathrm{E}$ & \\
\hline & & MNHN-IA- & \multirow[t]{2}{*}{ KY555062 } & & \\
\hline & & TYPE 1789 & & & \\
\hline & & MNHN-IA- & \multirow[t]{2}{*}{ KY555063 } & & \\
\hline & & TYPE 1790 & & & \\
\hline \multirow[t]{6}{*}{ Loimia sp. } & Thailand, Phuket & & AF342685 & - & Colgan et al. (2001) \\
\hline & India, Vellar estuary & VB-2018 & MG251651 & - & Direct Submission \\
\hline & \multirow[t]{4}{*}{ India, Goa } & GP0285 & KX525508 & $15^{\circ} 34^{\prime} 12.00^{\prime \prime} \mathrm{N}$ & Rengaiyan et al. (2016) \\
\hline & & GP0286 & KX525509 & $73^{\circ} 44^{\prime} 24.00^{\prime \prime} \mathrm{E}$ & (Unpublished) \\
\hline & & GP0287 & KX525510 & & \\
\hline & & GP0288 & KX525511 & & \\
\hline Pista cristata Müller, 1776 & Norway, Trondhejmsfjord & $\mathrm{H} 88$ & MG270116 & - & Eilertsen et al. (2017) \\
\hline \multirow[t]{2}{*}{ Terebella lapidaria Linnaeus, 1767} & \multirow[t]{2}{*}{ United Kingdom } & \multirow[t]{2}{*}{ SIO:BIC:A1102 } & \multirow[t]{2}{*}{ JX423771 } & $50^{\circ} 21.00^{\prime} \mathrm{N}$ & \multirow[t]{2}{*}{ Stiller J et al. (2013) } \\
\hline & & & & $4^{\circ} 07^{\prime} 48.00^{\prime \prime} \mathrm{W}$ & \\
\hline
\end{tabular}




\section{Table 2 (on next page)}

Primer information.

Information of primers used for amplification and sequencing. 
1

\begin{tabular}{|c|c|c|c|}
\hline Gene & Primer & Sequence $\left(5^{\prime}-3^{\prime}\right)$ & References \\
\hline \multirow{6}{*}{$\mathrm{COI}$} & LCO1490 & GGTCAACAAATCATAAAGATATTGG & Folmer et al. (1994) \\
\hline & HCO2198 & TAAACTTCAGGGTGACCAAAAA ATCA & Folmer et al. (1994) \\
\hline & CO1-E & TATACTTCTGGGTGTCCGAAGAATCA & Carr et al. (2011) \\
\hline & PolyLCO & GAYTATWTTCAACAAATCATAAAGATATTGG & Carr et al. (2011) \\
\hline & PolyHCO & TAMACTTCWGGGTGACCAAARAATCA & Carr et al. (2011) \\
\hline & PolyshortCOIR & CCNCCTCCNGCWGGRTCRAARAA & Carr et al. (2011) \\
\hline
\end{tabular}

2 


\section{Table 3(on next page)}

Morphological variations within the type-series of $L$. borealis sp. $n$.

Characters used to compare and morphological variations within types series of $L$. borealis $\mathrm{sp}$. $\mathrm{n}$.. Abbreviations: $L=$ length; $W=$ width; $A=$ absen. 


\begin{tabular}{|c|c|c|c|c|c|c|c|c|c|}
\hline & $\begin{array}{c}\text { Holotype } \\
\text { MBM286585 }\end{array}$ & $\begin{array}{c}\text { Paratype } 1 \\
\text { MBM286586 }\end{array}$ & $\begin{array}{c}\text { Paratype } 2 \\
\text { MBM286587 }\end{array}$ & $\begin{array}{c}\text { Paratype } 3 \\
\text { MBM286588 }\end{array}$ & $\begin{array}{c}\text { Paratype } 4 \\
\text { MBM286589 }\end{array}$ & $\begin{array}{c}\text { Paratype } 5 \\
\text { MBM286590 }\end{array}$ & $\begin{array}{c}\text { Paratype } 6 \\
\text { MBM286591 }\end{array}$ & $\begin{array}{c}\text { Paratype } 7 \\
\text { MBM286592 }\end{array}$ & $\begin{array}{c}\text { Paratype } 8 \\
\text { MBM286593 }\end{array}$ \\
\hline $\begin{array}{c}\text { Oversize } \\
(\mathrm{L} / \mathrm{M}, \mathrm{mm})\end{array}$ & $82.8 / 13.2$ & $77.3 / 11.9$ & $73.3 / 13.2$ & $72.7 / 6.9$ & $59.6 / 12.0$ & $80.5 / 7.8$ & $63.2 / 9.7$ & $63.5 / 10$ & $72.7 / 11.5$ \\
\hline $\begin{array}{l}\text { Number of } \\
\text { segments }\end{array}$ & 104 & 101 & 104 & 95 & 85 (broken) & 90 & 88 (broken) & 55 (broken) & 94 \\
\hline Eyespots & A & A & A & A & $\mathrm{A}$ & A & A & A & A \\
\hline $\begin{array}{c}\text { shields } \\
\text { (numbers) }\end{array}$ & $\begin{array}{l}\text { divided into } 2 \\
\text { or more } \\
\text { transverse } \\
\text { lines }\end{array}$ & $\begin{array}{l}\text { segments } \\
\text { divided into } \\
2 \text { or more } \\
\text { transverse } \\
\text { lines }\end{array}$ & $\begin{array}{l}\text { segments } \\
\text { divided into } 2 \\
\text { or more } \\
\text { transverse } \\
\text { lines }\end{array}$ & $\begin{array}{l}\text { segments } \\
\text { divided into } \\
2 \text { or more } \\
\text { transverse } \\
\text { lines }\end{array}$ & $\begin{array}{l}\text { segments } \\
\text { divided into } \\
2 \text { or more } \\
\text { transverse } \\
\text { lines }\end{array}$ & $\begin{array}{l}\text { segments } \\
\text { divided into } \\
2 \text { or more } \\
\text { transverse } \\
\quad \text { lines }\end{array}$ & $\begin{array}{l}\text { segments } \\
\text { divided into } \\
2 \text { or more } \\
\text { transverse } \\
\text { lines }\end{array}$ & $\begin{array}{l}3 \text { fused, } 2 \text { last } \\
\text { segments } \\
\text { divided into } 2 \\
\text { or more } \\
\text { transverse } \\
\text { lines }\end{array}$ & $\begin{array}{l}\text { shields, } 2 \text { last } \\
\text { segments } \\
\text { divided into } \\
\text { transverse } \\
\text { lines }\end{array}$ \\
\hline $\begin{array}{c}\text { Genital } \\
\text { papillae } \\
\text { (segments) }\end{array}$ & $6-8$ & $6-8$ & $6-8$ & - & - & - & - & $6-8$ & $6-8$ \\
\hline $\begin{array}{l}\text { Number of } \\
\text { teeth (anterior } \\
\text { x posterior } \\
\text { uncini) }\end{array}$ & $5-6 \times 6$ & $4-5 \times 4-5$ & $5-6 \times 5-6$ & $6 \times 6$ & $5-6 \times 5-6$ & $5-6 \times 5-6$ & $6 \times 5-6$ & $5-6 \times 5$ & $5-6 \times 5-6$ \\
\hline
\end{tabular}




\section{Table 4 (on next page)}

List of species of Loimia used for comparison.

A list of Loimia species used for comparison with main morphological characters used for the identification. Sources: Grube (1878); Moore (1903); Caullery (1944); Hutchings \& Glasby (1988); Hutchings (1990); Hutchings \& Glasby (1995); Londoño-Mesa \& Carrera-Parra (2005);

Carrerette \& Nogueira (2015). Abbreviations: $L=$ length; $W=$ width; $A=$ absent; $P=$ present. 


\begin{tabular}{|c|c|c|c|c|c|c|c|c|c|}
\hline & $\begin{array}{c}\text { Type } \\
\text { locality }\end{array}$ & $\begin{array}{l}\text { Size } \\
(\mathrm{L} / \mathrm{M}, \\
\mathrm{mm})\end{array}$ & $\begin{array}{c}\text { Eyespot } \\
\text { s }\end{array}$ & Prostomium & Lateral lobes, segment 1 & Lateral lobes, segment 3 & Shape of branchiae & $\begin{array}{c}\text { Ventral } \\
\text { shields (segs } \\
\text { and shape) }\end{array}$ & $\begin{array}{l}\text { Uncini } \\
\text { (number } \\
\text { of teeth) }\end{array}$ \\
\hline L. bandera & $\begin{array}{c}\text { Pacific } \\
\text { Ocean, } \\
\text { Hong Kong }\end{array}$ & $30 / 3$ & A & $\begin{array}{l}\text { Compact with } \\
\text { expanded } \\
\text { anterior lip with } \\
\text { convoluted } \\
\text { margins }\end{array}$ & $\begin{array}{l}\text { Originating laterally as } \\
\text { rounded elongate lobes } \\
\text { with extend ventrally as } \\
\text { an elevated collar } \\
\text { connected mid-ventrally }\end{array}$ & $\begin{array}{l}\text { Recurved free lateral } \\
\text { lobes fused to dorsal- } \\
\text { lateral margin of } \\
\text { segment } 3 \text { and almost } \\
\text { fused onto anterior } \\
\text { margin of segment } 4\end{array}$ & $\begin{array}{l}\text { Decreasing in size from } \\
\text { segment } 2-4, \text { with short thick } \\
\text { main stalk and dichotomous } \\
\text { branching secondary stalks; } \\
\text { terminal branches short, fine } \\
\text { and spirally }\end{array}$ & $\begin{array}{l}3-12, \\
\text { rectangular }\end{array}$ & $5-6$ \\
\hline L. arborea & $\begin{array}{c}\text { Suruga bay, } \\
\text { Japan }\end{array}$ & $120 / 10$ & A & $\begin{array}{l}\text { Broad, } \\
\text { prominent, } \\
\text { almost } \\
\text { surrounding the } \\
\text { mouth }\end{array}$ & $\begin{array}{l}\text { Conspicuous rounded } \\
\text { lobes ending on the dorsal } \\
\text { surface with a pair of } \\
\text { smooth rounded } \\
\text { eminences. }\end{array}$ & $\begin{array}{l}\text { Prominent dorso-lateral } \\
\text { lobes fused to segment } \\
2 \text { and partly to segment } \\
3\end{array}$ & $\begin{array}{l}\text { The first the largest, and the } \\
\text { third slightly the smallest, all } \\
\text { arborescent with about } 6 \text { main } \\
\text { branches from a central } \\
\text { arrangement, forming a } \\
\text { conical shape. }\end{array}$ & $\begin{array}{c}3-11, \\
\text { rectangular } \\
\text { becoming } \\
\text { rapidly } \\
\text { smaller as } \\
\text { the tori } \\
\text { extend }\end{array}$ & $6-7$ \\
\hline L. ingens & $\begin{array}{c}\text { SE Asia, } \\
\text { Philippines }\end{array}$ & $30 / 5$ & $\mathrm{~A} / \mathrm{P}$ & $\begin{array}{c}\text { Compact, collar } \\
\text { like }\end{array}$ & $\begin{array}{l}\text { Rounded lobes fused to } \\
\text { each other mid-ventrally, } \\
\text { forming a collar across } \\
\text { dorsum }\end{array}$ & $\begin{array}{l}\text { Prominent and rounded } \\
\text { lobes fused laterally } \\
\text { with segments } 2 \text { and } 3\end{array}$ & $\begin{array}{l}\text { The first and second pair } \\
\text { about the same size, the third } \\
\text { the smallest; each with long } \\
\text { basal stem, dendritic } \\
\text { branching subdistally, distally } \\
\text { loosely spiraled filaments }\end{array}$ & $\begin{array}{l}\text { 3-14, } \\
\text { rectangular } \\
\text { to } \\
\text { trapeziform }\end{array}$ & $3-7$ \\
\hline
\end{tabular}


3 Table 4 (continued)

\begin{tabular}{|c|c|c|c|c|c|c|c|c|c|}
\hline & $\begin{array}{c}\text { Type } \\
\text { locality }\end{array}$ & $\begin{array}{c}\text { Size (L/M, } \\
\mathrm{mm})\end{array}$ & Eyespots & Prostomium & Lateral lobes, segment 1 & Lateral lobes, segment 3 & Shape of branchiae & $\begin{array}{l}\text { Ventral shields } \\
\text { (segs and } \\
\text { shape) }\end{array}$ & $\begin{array}{c}\text { Uncini } \\
\text { (number of } \\
\text { teeth) }\end{array}$ \\
\hline L. medusa & Red Sea & $32 / 2.1$ & $\mathrm{P}$ & $\begin{array}{c}\text { Compact, collar } \\
\text { like }\end{array}$ & $\begin{array}{l}\text { Large, anteriorly directed } \\
\text { ventrally and forming } \\
\text { scoop ventrally }\end{array}$ & $\begin{array}{l}\text { Large, ear-shape, not } \\
\text { extending ventrally; not } \\
\text { sure derived from } \\
\text { segment } 2 \text { and } 3 \text { or just } \\
3\end{array}$ & $\begin{array}{l}\text { The first pair very long, } \\
\text { about } 3 \text { times body width; } \\
\text { the third the smallest; each } \\
\text { with main stem and many } \\
\text { short dendritic branches }\end{array}$ & $\begin{array}{l}\text { 3-12, } \\
\text { rectangular } \\
\text { and } \\
\text { trapeziform }\end{array}$ & $4-5$ \\
\hline L. montagui & $\begin{array}{c}\text { Philippine } \\
\text { Islands }\end{array}$ & $35-50 /-$ & A & $\begin{array}{l}\text { Large in size, } \\
\text { offering a wide } \\
\text { cross-sectional } \\
\text { black stripe at } \\
\text { its base. }\end{array}$ & $\begin{array}{l}\text { Foliaceous lobes, with } \\
\text { rounded end, connecting } \\
\text { each other by a } \\
\text { membrane. }\end{array}$ & Low, rounded end & $\begin{array}{l}\text { Decreasing in size from } \\
\text { segment 2-4, short } \\
\text { branchial filaments } \\
\text { branching dichotomously } \\
\text { from secondary stems } \\
\text { originating from short } \\
\text { basal stems }\end{array}$ & $\begin{array}{c}\text { 3-14, first six } \\
\text { rectangular, } \\
\text { last two } \\
\text { trapeziform }\end{array}$ & $5-6$ \\
\hline
\end{tabular}

